\title{
I. A comparison of Rowland's mercury thermometers with a Callendar-Griffiths' platinum thermometer; a comparison of the platinum thermometer with a Tonnelot thermometer standardized at the Bureau International; and a reduction of Rowland's value of the mechanical equivalent of heat to the Paris nitrogen scale
}

\author{
Charles W. Waidner Jr. \& Francis Mallory
}

To cite this article: Charles W. Waidner Jr. \& Francis Mallory (1899) I. A comparison of Rowland's mercury thermometers with a Callendar-Griffiths' platinum thermometer; a comparison of the platinum thermometer with a Tonnelot thermometer standardized at the Bureau International; and a reduction of Rowland's value of the mechanical equivalent of heat to the Paris nitrogen scale, Philosophical Magazine Series 5, 48:290, 1-45, DOI:

10.1080/14786449908621303

To link to this article: http://dx.doi.org/10.1080/14786449908621303

\section{曲 Published online: 08 May 2009.}

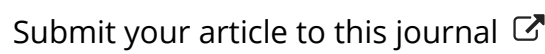

Џ Article views: 3

View related articles $־$ 
T HE

\title{
LONDON, EDINBURGH, AND DUBLIN \\ PHII.OSOPHICAL MAGAZINE
}

\author{
AND \\ JOURNAL OF SCIENCE. \\ [FIFTH SERIES.] \\ $J U L Y 1899$.
}

I. A Comparison of Rowland's Mercury Thermometers with a Callendar-Griffiths' Platinum Thermometer ; a Comparison of the Platinum Thermometer with a Tonnelot Thermometer standardized at the Bureau International; and $a$ Keduction of Rowland's Value of the Mechanical Equivalent of Heat to the Paris Nitrogen Scale. By CharLes W. Waidner, Jr., and Francis Mallort*.

THE recent determinations of the mechanical equivalent of 1 heat by electrical methods, while in fair agreement among themselves, seem to give results considerably higher than those obtained by experimenters using the more direct mechanical methods; these differences, which are probably greater than the errors of experiment, must be due to a difference in the standards of thermometry employed or to a still undiscovered error in the system of electric units. The object of the present investigation was to obtain a connexion between Rowland's standard of thermometry and that employed in the electrical determinations of the equivalent, in order to render the different determinations more easily comparable.

Joule compared his thermometer with Rowland's Baudin 6166 (Proc. Amer. Acad. xvi. p. 38, 1880), and in this way Joule's determinations of the mechanical equivalent have been reduced to the Rowland "air-scale." By a further elaborate comparison by Prof. Schuster (Phil. Mag.xxxix. 1895)

* Communicated by Prof. H. A. Rowland. An abstract of this investigation was read at the Toronto meeting of the British Association, and a preliminary account appeared in the Johns Hopkins University Circulars, June 1897, 1898.

Phil. Mag. S. 5. Vol. 48. No. 290. July 1899. 
of Joule's thermometers with a thermometer standarized at the Bureau International, an indirect connexion was obtained between Rowland's Air-scale and the Nitrogen-scale of the Burean International. This comparison pointed to differences in the two scales as great as $0^{\circ} .05 \mathrm{C}$. Inasmuch as the details of the method employed by Joule in his comparison are not known, Professor Ames suggested that another more direst comparison of Professor Rowland's thermometers was desirable.

\section{Method of Comparison.}

As we wished to use the results of this experiment to reduce Rowland's valnes of the equivalent to the scales used by experimenters employing the electrical methods, and thus render the results comparable, it was deemed best to make the comparisons of these thermometers under conditions as nearly as possible the same as those under which they were employed by him in his experiments on the mechanical equivalent. For this reason, a Callendar-Griffiths' platinum thermometer was selected for the comparison. This instrument offers many advantages for the standardization of calorimetric thermometers. The platinum thermometer was subsequently compared with a Tonnelot thermometer standardized at the Bureau International. A connexion was this obtained between Rowland's air-seale and the Callendar-Griffiths' air-scale, as well as with the nitrogen-scale of the Bureau International.

The zero readings of the mercury thermometers were taken in the same way that Rowland used them, before each comparison. The thermometers were placed in a metallic vessel well wrapped with thick felt and filled with finely cracked ice of great purity steeped with distilled water. After they had remained in ice about one and one-half hours, the zero readings were taken by means of a micrometer-telescope. The mercury thermometer was then hastily transferred to a well stirred calorimeter with its bulb near that of the platinum thermometer. The temperature of the water in the calorimeter at the start was generally about $2^{\circ}$ or $3^{\circ} \mathrm{C}$. A series of five or six readings on the mercury thermometer was then taken by one observer with the aid of a micrometer telescope, while the other observer took simultaneous readings of the resistance of the platinum thermometer.

The temperature of the water in the calorimeter was then raised at a rate of about $10^{\circ}$ to $15^{\circ}$ per hour to the next temperature at which a comparison was to be made; this was accomplished by sending a suitable current through a coil wrapped on the outside of the calorimeter. When the desired temperature was reached, the current was cut off or so regulated that the temperature was very slowly rising, when 
a further series of simultaneous observations were taken, and so on to the end of the scale.

The mercury thermometers were used in a vertical position, and all observations were taken while the meniscus was very slowly rising, usually at a rate of about .002 or $.003^{\circ}$ per minute, so that the slight uncertainties of a falling meniscus were avoided. At the point where the thermometer emerges from the calorimeter, it is surrounded by a small water-jacket in which a small thermometer and stirrer are placed. The temperature of the mercury column above the water-jacket is assumed to be that of the surrounding air as indicated by a thermometer hung within an inch or two of the stem. Thus the stem correction was applied in two parts by means of the formula $\Delta \mathrm{N}=\cdot 000156 n\left(t-t^{\prime}\right)$, where $\Delta \mathrm{N}$ is the correction to the observed stem-reading, $t$ the observed temperature, $t^{\prime}$ the temperature of that portion of the stem emerging from the calorimeter, and $\mathrm{N}$ the number of stemdivisions at the temperature $t^{\prime}$. The stem correction was applied to the observed stem-reading, and the corresponding temperature on Rowland's air-scale was then taken from his tabies (Proc. Amer. Acad. xv. 1879, pp. 115 \& 116); this temperature was then reduced by the rise of the zero since Rowland's experiments.

The corresponding temperature on the Callendar-Griffiths' air-scale was obtained from the observed resistance of the platinum thermometer ; the way in which this was done will be explained more fully later.

\section{Manner in which Baudin Thermometers were used by Professor Rowland.}

These thermometers were first calibrated by measuring the length of a short column of mercury in different portions of the stem, and in this way the relative volumes of different parts of the tube were found. Temperature on the mercuryin-glass thermometers was then defined as proportional to the apparent volume of mercury in glass, when the thermometer is vertical. It was then assumed that the apparent volume of mercury-in-glass could be expressed as a function of the second degree of the temperature on the air thermometer, of the following form :

$$
\mathrm{T}=\mathrm{C}^{\prime} \mathrm{V}-t_{0}^{\prime}-n \mathrm{~T}(40-\mathrm{T})\{1-n(40+\mathrm{T})\}
$$

using the $0^{\circ}$ and $40^{\circ}$ points as fixed by the air thermometer; where $\mathrm{T}$ is the temperature on the air thermometer,

$\mathrm{V}$ is the volume of the stem of the mercurial thermometer, as determined by the calibration, and measured from any arbitrary point,

$\mathrm{C}, t_{0}{ }^{\prime}, m, n$ are constants to be determined. 
From a series of direct comparisons of the mercurial thermometers with a standard air thermometer, a number of equations of the above form were obtained, from which the most probable values of these constants were dednced by the method of least squares.

From these formulæ tables were constructed giving the temperature on the scale of the standard air thermometer corresponding to each centimetre of the stem. These tables are found on pp. $115 \& 116$, Proc. Amer. Acad. xv. 1879.

These thermometers were always used with a constant zero determined before each series of observations, by immersing the thermometer in a mixture of finely cracked ice and distilled water for a period of one or two hours. As the position of the zero, owing to the imperfect elasticity of the glass, depends on the temperature to which the thermometer has been subjected recently, the thermometers were always kept at least one week at a temperature of about $20^{\circ} \mathrm{C}$. before they were used in a comparison, or in a determination of the mechanical equivalent, in which interral the zero will have almost recovered from the depression due to a recent heating of the thermometer.

In the original comparisons of these thermometers with the air thermometer, no corrections were necessary for internal pressure due to the mercury column and meniscus, as the thermometers were compared and always used in a vertical position. A correction for external pressure was made, due to about 60 cms. of water in the comparison tank.

In the experiments on the mechanical equivalent, the thermometer was placed in the calorimeter with the top of the bulb about $5 \mathrm{~cm}$. below the surface of the water, and the remainder of the stem projected out into the air. The stem correction was then applied in two parts by surrounding the stem, where it projected from the calorimeter, with a small water-jacket, the remainder of the stem being assumed to be at the temperature of the surrounding air.

\section{Platinum Thermometry.}

The measurement of temperature by means of the variation of resistance of a wire was first seriously proposed by Siemens, who submitted for trial to a committee of the British Association some platinum-resistance pyrometers (Brit. Asscc. Report 1874). The results of these experiments were unfavourable to the use of the platinum-resistance thermometer as a scientific instrument of precision. It was found that, for this type of pyrometer, the resistance of the platinum wire was not a constant for a fixed temperature, but depended greatly 
on the previous history of the wire. The development of this type of thermometer was next taken up by Callendar, who, in an exhaustive series of researches (Phil. Trans. Roy. Soc., vol. clxxviii. A), showed that if the platinum wire is fairly pure to begin with, and if it has been well annealed, the resistance is always the same at the same temperature, even if the wire has been repeatedly exposed to quite high temperatures in the interval. In the light of these researches, it is plain that the failure of the Siemens' resistance pyrometer was simply due to faulty construction, which exposed the wire to the action of injurious vapours \&c. from the clay on which it was wound and the iron cylinder in which it was enclosed.

The extensive researches of Dewar and Fleming (Phil. Mag. 1893) and Cailletet and Colardeau (J. de Phys. t. viii. 1888) at very low temperatures, and those of Heycock and Neville (Chem. Soc. Trans. 1895) at very high temperatures, taken with those of Callendar and Griffiths (Phil. Trans. Roy. Soc. vol. clxxriii. A, 1887; rol. clxxxii. A, 1891) at ordinary temperatures, establish beyond a doubt the remarkable accuracy and constancy of this instrument over a very wide range of temperature.

Temperature on the platinum scale is defined by the equation

$$
p t=\frac{\mathbf{R}-\mathbf{R}_{0}}{\mathbf{R}_{1}-\overline{\mathbf{R}}_{0}} \times 100,
$$

where $p t$ denotes the platimum temperuture, $\mathrm{R}$ the resistance of the platinum coil of the thermometer at that temperature, $R_{0}$ its resistance at $0^{\circ} \mathrm{C}$., and $R_{1}$ the resistance at $100^{\circ} \mathrm{C}$. From the above definition it is seen that platinum temperature is independent of the unit of resistance employed.

Callendar and Griffiths, in an elaborate comparison of the platinum and air thermometers (Phil. Trans. Roy. Soc. vol. clxxxii. A, 18:1), have shown that the relation between the two scales of temperature can be expressed by an equation of the form

$$
t-p t=\delta\left\{\left(\frac{t}{100}\right)^{2}-\frac{t}{100}\right\},
$$

where $t$ is the temperature on the air-scale, $p t$ the platinum temperature as defined above, and $\delta$ a constant depending on the specimen of wire used. This relation being a parabolic one, only three temperatures are necessary for the complete standardization of a platinum thermometer, $i . e$., for the determination of $\delta$. Two temperatures always used for this purpose are that of melting ice, $0^{\circ} \mathrm{C}$, and that of water boiling freely under a pressure of $760 \mathrm{~mm}$. of mercury whose 
density is that of $0^{\circ} \mathrm{C}$., sea-level latitude $45^{\circ}, 100^{\circ} \mathrm{C}$. For the third temperature the boiling-point of some substance, which is accurately known from a direct neasurement with an air-thermometer, is used. The one most frequently used is the boiling-point of sulphur, $t=444^{\circ} \cdot 53$, on account of the accuracy with which it is known. Callendar and Griffiths have shown that if platinum thermometers be standardized by these three temperatures (melting ice, stenm sulphur vapour), the above formula will give temperatures on the airscale to within $0^{\circ} 01 \mathrm{C}$. over the range $0^{\circ} \mathrm{C}$. to $100^{\circ} \mathrm{C}$. This conclusion is further confirmed by a direct comparison made by Dr. W. S. Day and the authors between a platinum thermometer and a Tonnelot thermometer standardized at the Bureau International, whose scale of temperature is based on measurements made with a constant-volume gas thermometer. The comparison referred to above, made by Callendar and Griffiths, is based on a constant-pressure air thermometer.

\section{Description of Apparatus.}

Mercury Thermometers. - The thermometers used by Rowland in his experiments on the mechanical equivalent were constructed by Baudin in 1876-77, and are numbered 6163, 6165 , and 6166. Of these thermometers, Baudin 6163 is perhaps the most important, as it was used in eight of the fourteen determinations. Baudin 6166 was used in four determinations, and has besides an historical interest, as Joule compared his thermometers with it; Baudin 6165 was used in only one determination of the mechanical equivalent. Besides these, Kew 104, constructed by Welsh in 1853, was used in one determination. This thermometer was not available for this comparison, but inasmuch as it was only calibrated to $0^{\circ} .5 \mathrm{~F}$., and was given but little weight in the final results, its effect on the values of the mechanical equivalent is entirely negligible.

The stems of the thermometers are graduated in millimetres.

\begin{tabular}{|c|c|c|c|c|c|}
\hline \multicolumn{3}{|c|}{ Thermometer. } & Range. & \multicolumn{2}{|c|}{$1^{\circ} \mathrm{C}$. occupies about } \\
\hline $\mathrm{Bau}$ & 6163 & $\ldots \ldots$ & $-6^{\circ} \mathrm{C}$. to $40^{\circ} \mathrm{C}$. & $9 \cdot 0$ & $\mathrm{~nm}$. \\
\hline$"$ & 6165 & ...... & $-3^{\circ} \mathrm{C}$. to $33^{\circ} \mathrm{C}$ & $11 \cdot 7$ & " \\
\hline , & 6166 & ....... & $-2^{\circ} \mathrm{C}$. to $31^{\circ} \mathrm{C}$. & $12 \cdot 9$ & , \\
\hline
\end{tabular}

Platinum Thermometer.-The platinum thermometer used in these experiments, and shown in fig. 1, was constructed by 
Comparisons of Mercury and Platinum Thermometers. 7 the Cambridge Scientific Instrument Co., under the supervision of Mr. E. H. Griffiths. It consists of a coil of fine platinum wire wound on a mica frame whose edges are serrated to receive the windings. The thick leads rumning down to this coil are held apart by mica washers, and the whole thermometer is enclosed in a thin glass tube. The thick leads are connected with the terminals marked P P.

Fig. 1.
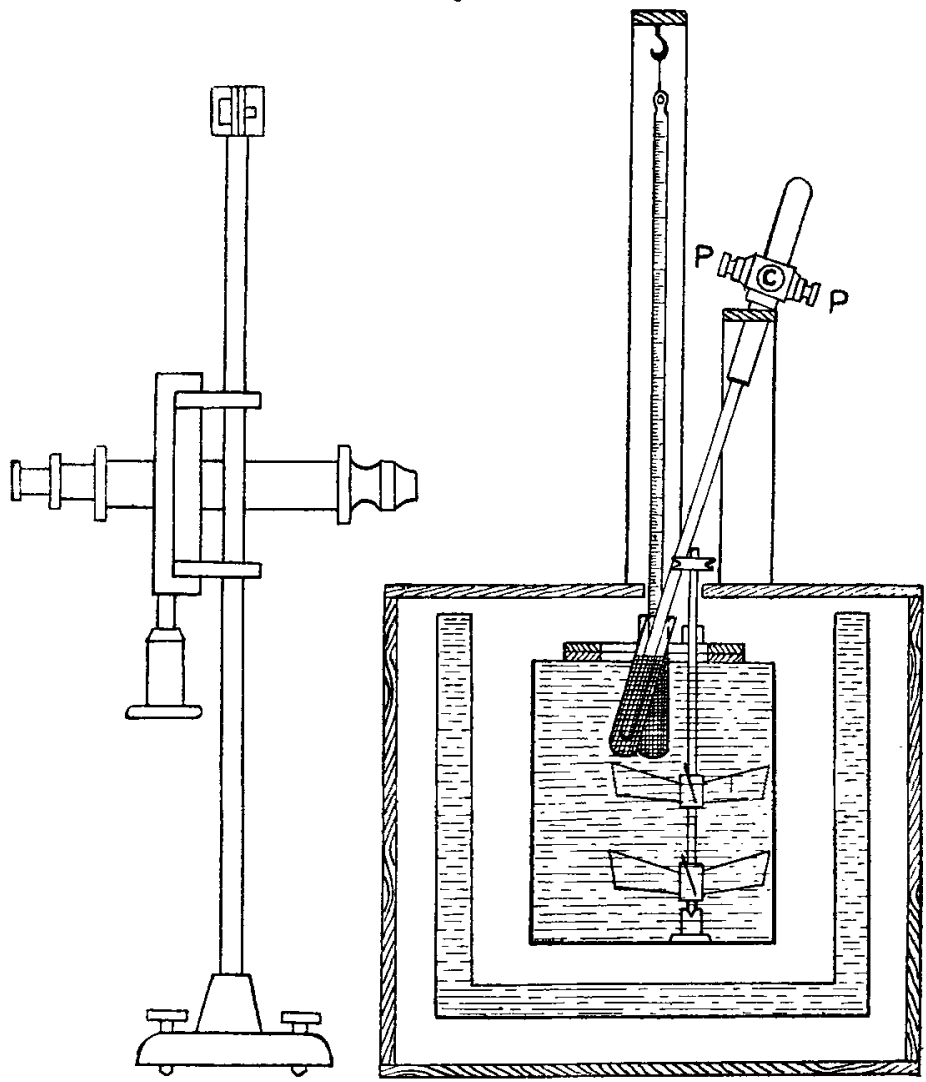

This thermometer was also provided with compensating leads, so that its indications are independent of the depth of stemimmersion, provided this immersion is sufficient to prevent conduction from the outside along the leads to the coil. The compensating leads C C are simply a loop (not connected with the platinum coil) running down the stem parallel to the main leads P P throughout their length, so that they are 
exposed to the same temperature changes. These compensating leads are adjusted so that their resistance is equal to that of the main leads P P. Now, obviously, if these leads C C are placed in the other arm of the Wheatstone-bridge, as shown in fig. 2 below, they will exactly compensate for the change in resistance of the leads to the coil, and consequently the resistance we measure, and hence the temperature, is independent of the depth of the immersion of the thermometer in the liquid or vapour whose temperature is sought. A little consideration will show that it is not necessary that the resistance of the compensating leads be exactly equal to the leads to the coil in order to have compensation. It is only necessary that they be so nearly equal that the temperature changes of their difference produce no appreciable effect on the resistance.

Calorimeter.-The calorimeter, in which these comparisons were made (shown in fig. 1), was made of copper and provided with an efficient stirrer, which was driven by a small hot-air engine. The outside of the calorimeter was closely wrapped with a coil of single silk-covered germansilver wire, so that the temperature of the calorimeter and its contents could be raised at any desired rate by an electric current of suitable strength. The calorimeter was placed inside a large double-wall copper vessel (ext. diam. $36 \mathrm{~cm}$., ht. $35 \mathrm{~cm}$.), which surrounded it on all sides except the top. The space between these walls $(2.5 \mathrm{~cm}$. apart) could be filled with water at any desired temperature, and thus the temperature of the calorimeter could be maintained constant for some minutes or caused to vary at will. The entire arrangement was then surrounded by a large box $(46 \mathrm{~cm}$. on the side), and all intervening spaces packed loosely with feathers.

Resistance-Box. - The resistance-measurements of the platinum thermometer were made with a Callendar-Griffiths resistance-box (No. 7) especially designed for the measurement of platinum temperature. The construction and calibration of a resistance-box similar to the one used by us has been described by Mr. E. H. Griffiths in 'Nature,' Nov. 14th, 1895. A general idea of the construction of the box may be gathered from the following diagrammatic sketch.

$A_{1}, A_{2}$ are two equal coils which serve as the equal arms of a Wheatstone-bridge. The coils of the box, which were made of platinum-silver, have approximately the following nominal values in box-units (approximately, one box unit= $0.01 \mathrm{ohm}):-$

$\begin{array}{ccccccccc}\text { H } & \text { G } & \text { F } & \text { E } & \text { D } & \text { C } & \text { B } & \text { A } & \text { FI } \\ \mathbf{5} & 10 & 20 & 40 & 80 & 160 & 320 & 640 & 100\end{array}$


The bridge-wire $W W$ was made of platinum-silver, was $30 \mathrm{~cm}$. long, and bad a resistance of about $0.30 \mathrm{ohm}$. Contact was made with the galvanometer through a similar wire stretched parallel to the bridge-wire. The point of contact

Fig. 2.

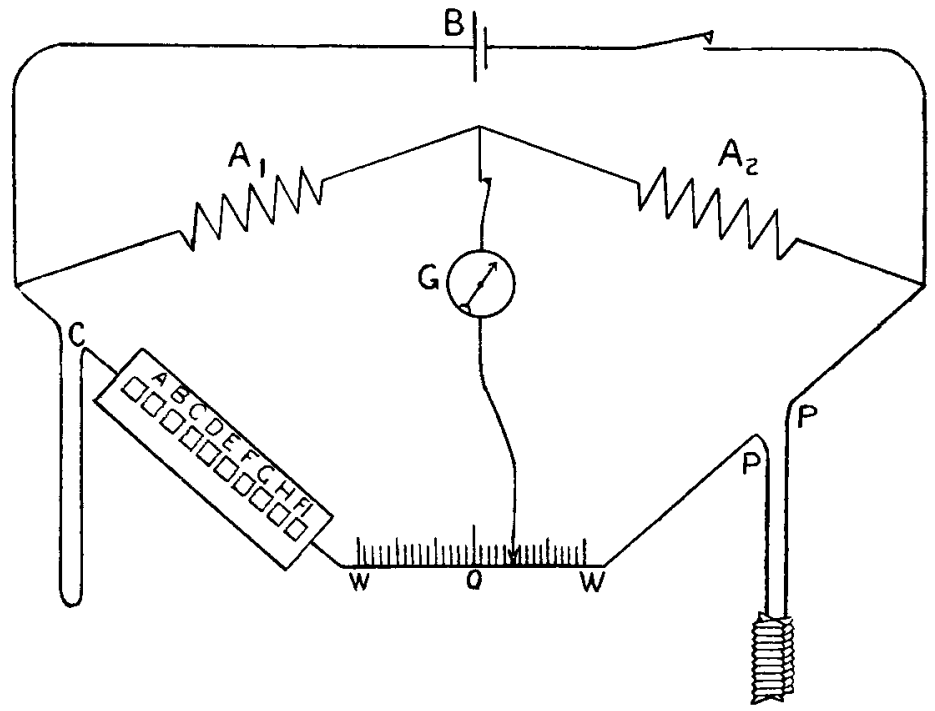

was determined by a very carefully constructed contact-key carrying a vernier reading directly to $\frac{1}{50} \mathrm{~mm}$., so that $\frac{1}{100} \mathrm{~mm}$. was easily estimated (corresponding to about $0.00001 \mathrm{ohm}$ ). This ingenious contact-key, which was designed by Mr. Horace Darwin, renders any injury to the bridge-wire almost impossible. The scale and bridge-wire are connected in such a way that the readings are practically unaffected by very considerable changes in temperature. The leads to the coil of the platinum thermometer were connected to the terminals $\mathrm{P} \mathrm{P}$ and the compensating leads to the terminals $\mathrm{C} \mathrm{C}$. The galvanometer is shown at $G$, and the battery at $B$.

When the intervals $\mathrm{C}$ to $\mathrm{C}$ and $\mathrm{P}$ to $\mathrm{P}$ were short-circuited by strips of copper, and all plugs inserted, the bridge was balanced when contact was made with the bridge-wire at some point very near the eentre, $O$. The reading of the bridge-wire when the bridge was balanced under these conditions is called the zero correction to the bridge-wire. The platinum thermometer was then inserted, and its resistance at any temperature could be measured by suitable combinations of coils and bridge-wire. The corrections to reduce the 
nominal values of the coils to mean box-units at some standard temperature, as determined by a previous calibration of the box, were then applied, as well as the corrections to reduce the bridge-wire readings to mean box-units. The resistance of the platinum thermometer was then known in terms of the mean box-unit. Any resistance could be measured with several different combinations of coils and bridge-wire, and thus the accuracy of the measurements was exposed to a severe test.

The top of the box was constructed of white marble, which was found to have a very high insulation resistance. The brass plugs were large and carefully ground, but at no point were they larger than the top of the hole into which they were inserted. This is a very important detail, as it insures the impossibility of wearing a shoulder on the plug, in which case no amount of pressure will give good contact.

This box was also provided with small switches by which resistances could be tbrown into the battery-circuit and the galvanometer shunted, which proved a great convenience in finding an approximate balance.

The bridge was always used with a key by which the circuits could be closed and opened in such a way that the effects of thermoelectric currents were eliminated.

In these experiments the resistance-box was supported in a large double-wall copper tank. The inner compartment of this tank, in which the resistance-coils are placed, is filled with a highly insulating neutral oil, which sereral careful tests showed to be free from acid or alkali. The outer compartment was filled with water which was maintained at a nearly constant temperature by a suitable thermal regulator. The top of the box was enclosed in a glass case, thus preventing sudden changes in the temperature of the top of the box and the bridge-wire and the accumulation of dust.

We take this opportunity to express our deep sense of obligation to the authorities of the University of Chicago, who, through the kindness of Professor W. S. Stratton of the Ryerson Physical Laboratory, placed this valuable apparatus at our disposal for this investigation.

Galvanometer.-The galvanometer was of the four-coil Thomson type, having what is practically a double metallic case so that the disturbing effects of air-currents are reduced to a minimum. The dimensions of these coils were $19 \mathrm{~mm}$. external diameter, $4 \mathrm{~mm}$. internal diameter, $8 \mathrm{~mm}$. deep, the distance between centres of coils when mounted being $25 \mathrm{~mm}$. Each coil was wound in three sections (Nos. 36, 33, and $30 \mathrm{~B} . \&$ S. wire being used) approximately according to 
the theoretical curves of best winding with a total of 530 turns. The coils were covered with gold-leaf, and in this way connected with the surrounding metallic case to avoid electrostatic disturbances. Tho resistance of each coil was about 13 ohms. The sensibility of this galvanometer with all the coils in parallel (Res. $=3 \cdot 2$ ohms) when tested with a Wiess suspension system (two vertical magnets $27 \mathrm{~mm}$. long, $1.5 \mathrm{~mm}$. apart, made of sinall magnetized sewing-needles and mounted on a thin strip of micn; total weight about 45 milligrammes) was $\mathrm{C}=6 \times 10^{-10}$ ampere; i. e., the current required to produce $1 \mathrm{~mm}$. defiexion on a scale 1 metre distant when the period of a complete swing was 10 seconds. When tested with a very light suspension system weighing abont 5 milligrammes (built of 10 or 12 magnets about $1 \mathrm{~mm}$. long each, made of fine watch-spring, tempered and strongly magnetized, total weight about 6 milligrammes), the sensibility under the same conditions was $\mathrm{C}=2.5 \times 10^{-10}$. All the magnets used in the suspension systems were repeatedly magnetized and boiled for several hours, so that magnets of great permanency were obtained. Throughout the present investigation the Wiess suspension system was used on account of its greater freedom from external disturbances.

Barometer and Standard Metre.-The barometer was of the Regnault standard type with a tube about $1 \mathrm{~m}$. in height and $25 \mathrm{~mm}$. internal diameter. The lower meniscus was defined by a steel screw of known length. The barometric height was measured on the standard metre bar placed beside the mercury column by means of a cathetometer. 'lhe barometric heights as measured by the scale on the cathetometer column, merely as a check, were always found to be in fair agreement with the values found by the standard metre. This barometer was compared with a Fortin standard barometer, and the agreement (to $\frac{1}{10} \mathrm{~mm}$.) was as close as we could read on the latter instrument.

The standard Bartel and Diedrich's metre was divided into millimetres, with the rulings on a strip of silver, imbedded in a bronze bar of square section about $21 \mathrm{~mm}$. on the side. The corrections to the divisions of this metre were known from previous comparisons with a standard steel metre which had been compared with the Coast Survey and other standards by Prof. Rogers.

\section{Standardization of Resistunce-Box.}

The resistance-box, mounted as already described, was twice standardized with the greatest care. While we cannot give within the limits of the present paper the details of the 
method used or the mass of figures involved, it is sufficient to state that the method was in general similar to the one described by Mr. E. H. Griffiths in 'Nature,' Nov. 14th, 1895. The figures given below are interesting as showing the degree of accuracy attainable. It will be seen that the two calibrations gave almost identical results.

Table I.

\begin{tabular}{|c|c|c|c|c|}
\hline \multirow{2}{*}{ Coils. } & \multirow{2}{*}{$\begin{array}{l}\text { Nominal values } \\
\text { in Box Cnits. } \\
\text { [approx. 1 B.U. } \\
=01 \text { ohm.] }\end{array}$} & \multicolumn{2}{|c|}{$\begin{array}{l}\text { Corrections (in mean B.U.) to } \\
\text { reduce uominal values to mean } \\
\text { box-units at } 20^{\circ} \mathrm{C} \text {. }\end{array}$} & \multirow{2}{*}{ Mean. } \\
\hline & & 1st Cal. & 2nd $\mathrm{Cal}$ & \\
\hline ....... & 5 & -0009 & -0007 & -001 \\
\hline G & 10 & $+\cdot 0012$ & $+\cdot 0036$ & +004 \\
\hline$F$ & 20 & $+\cdot 0312$ & +0310 & $+\cdot 031$ \\
\hline ......... & 40 & $+\cdot 0803$ & +0799 & +080 \\
\hline $\mathrm{D}$ & 80 & +0284 & +0277 & +028 \\
\hline ......... & 160 & -0415 & -0430 & -042 \\
\hline$\ldots \ldots$ & 320 & -0383 & -0362 & -.037 \\
\hline$\ldots \ldots \ldots$ & 640 & $-063 \pi$ & -0635 & -.063 \\
\hline FI. & 100 & $\ldots \ldots$ & $\ldots \ldots$ & +037 \\
\hline
\end{tabular}

Calibration of Eridge-wire.-This consists in finding the resistance of each centimetre of the bridge-wire in terms of the mean box-unit at some standard temperature. In re:istance-box No. 7 the scale of the bridge-wire, extending in each direction from the centre, is divided into centimetres, and very approximately $1 \mathrm{~cm}$. of the bridge-wire bas a resistance equal to 1 mean box-unit. The final results of the calibration are therefore given in the table below as a correction which is added to the bridge-wire reading (in $\mathrm{cms}$.) to reduce this to its equivalent resistance in mean box-units. The process is exactly similar to the calibration of a graduated glass tube, where the length of a short column of mercury is measured in different parts of the tube. A gauge-coil of manganin wire whose resistance was equal to about $2 \mathrm{cms}$. of the bridge-wire was balanced against different portions of the bridge-wire. Different parts of the bridge-wire (approx. 5 cms. long) were next balanced against the $H(5)$ coil of the resistance-box, and a connexion thus obtained between the bridge-wire and box-unit. 
TABLE II. - Correction to reduce the Bridge-wire Reading to the Mean Box Unit at $20^{\circ} \mathrm{C}$.

\begin{tabular}{|c|c|c|c|}
\hline $\begin{array}{l}\text { Bridge-wire } \\
\text { Reading. }\end{array}$ & $\begin{array}{l}\text { Calibration } \\
\text { Correction. }\end{array}$ & $\begin{array}{l}\text { Bridge.wire } \\
\text { Reading. }\end{array}$ & $\begin{array}{c}\text { Calibration } \\
\text { Correction. }\end{array}$ \\
\hline $\begin{array}{l}+05 \\
+1 \cdot 0 \\
+1 \cdot 5 \\
+2 \cdot 0 \\
+2 \cdot 5 \\
+3 \cdot 0 \\
+3 \cdot 5 \\
+4 \cdot 0 \\
+4 \cdot 5 \\
+5 \cdot 0 \\
+5 \cdot 5 \\
+6 \cdot 0 \\
+65 \\
+7 \cdot 0 \\
+7 \cdot 5 \\
+8 \cdot 0 \\
+8 \cdot 5 \\
+9 \cdot 0 \\
+9.5\end{array}$ & $\begin{array}{l}-.004 \\
-.007 \\
-.011 \\
-.015 \\
-.018 \\
-.022 \\
-.025 \\
-.028 \\
-.031 \\
-.034 \\
-.057 \\
-.041 \\
-.044 \\
-.047 \\
-.051 \\
-.054 \\
-.057 \\
-.060 \\
-.063\end{array}$ & $\begin{array}{l}-0.5 \\
-1.0 \\
-1.5 \\
-2.0 \\
-2.5 \\
-3.0 \\
-3.5 \\
-4.0 \\
-4.5 \\
-5.0 \\
-5.5 \\
-6 \cdot 0 \\
-6.5 \\
-7.0 \\
-7 \cdot 5 \\
-8.0 \\
-8.5 \\
-9.0 \\
-9.5\end{array}$ & 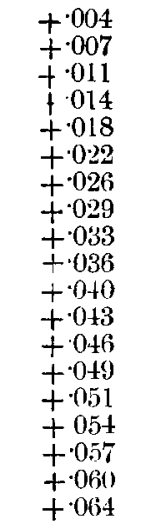 \\
\hline
\end{tabular}

The bridge-wire vernier could be easily read to the nearest ${ }_{10}^{1}$ mm., and this with considerable confidence. Observations of any constant resistance taken with the same combinations of coils and bridge-wire rarely differed by as much as $0.00002 \mathrm{ohm}$; when several different combinations were used to measure a constant resistance, as will be seen on referring to the measurement of $R_{0}$ (the resistance of the platinum thermometer at $0^{\circ} \mathrm{C}$.), the several measurements rarely differed by as much as $0.00005 \mathrm{ohm}$. This is a severe test of the accuracy of the standardization. Even these slight discrepancies are not entirely due to errors in calibration, but could, wo believe, be still further diminished by stirring the water in the outer tank surrounding the oil-bath in which the coils are immersed. Such great accuracy in the standardization of a resistance-box is, of course, easily obtained so long as we are only concerned with the relative values of the coils, which is all that we care about in the measurement of platinum temperature. But if the absolute values of the coils were required, a similar degree of accuracy would involve a vast amount of most painstaking work, mainly on account of the unscientific construction of most standard coils, which renders the accurate determination of their temperature impossible, and of their having undergone considerable changes in resistance with time. 
For the platinum thermometer used throughout this investigation a change in temperature of $0^{\circ} .001 \mathrm{C}$. corresponds to a change in resistance of about $0.00001 \mathrm{ohm}$. Owing to the great sensibility of the galvanometer, changes in resistance far more minute than the vernier would indicate (i.e. $0.00001 \mathrm{ohm}$ ) were easily detected. Advantage was taken of the high sensibility of the galvanometer to reduce the current used for measuring the resistance of the coil of the platinum thermometer to 0.002 or 0.003 of an ampere, thus almost entirely eliminating any heating up of the coil by the measuring current, which was only kept on for a few seconds at most. Perhaps an equally satisfactory method of reducing to a minimum the uncertain effects of heating of the platinum coil by the measuring current would be to so regulate the current through the coil that the energy used up in heating the coil is always the same at all temperatures.

\section{Constants of Platinum Thermometer.}

Determination of $\mathrm{R}_{0}$ (the resistance of the platinum thermometer at $0^{\circ} \mathrm{C}$.). - The ice used in these determinations was that manufactured by the Diamond Ice Co., of Baltimore, and was very clear and pure. The water used in this ice is first filtered; it is then frozen in large forms (long and high, but of shallow depth) from the sides towards the centre. When a thin sheet of water remains at the centre, the freezing is stopped and this water drawn off, thus insuring ice of great purity provided it is kept from contact with the freezing-mixture. Conductivity tests made on water obtained from this ice show a high specific resistance.

'The thermometer was inserted in a mixture of this ice (pounded very fine) and distilled water. In the first and second determinations of $\mathrm{R}_{0}$ a double-wall vessel was used, the inner vessel being nickel-plated. Ice and water were placed in both compartments. The outer vessel in all the zero determinations of the platinum, as well as for the mercurial thermometers, was wrapped with heavy boiler-felt to a thickness of about $4 \mathrm{cms}$.

The second and third determinations (Tables V. and VI.) were made in the same mixture of ice and distilled water, the only difference being that in the third the inner vessel was removed. The higher resistance obtained in this case (corresponding to about $0^{\circ} .002 \mathrm{C}$.) strongly suggests that, in a room whose temperature is $20^{\circ} \mathrm{C}$. above that of the thermometer, the effect of radiation cannot be neglected. We were at first of the opinion that the removal of the inner 
vessel would allow a more free circulation of the slightly warmed water coming from the top and sides, and thus the difference could be accounted for ; but considering the distance of the thermometer-coil from the top and sides, and the compactness of the ice, this does not seem possible.

The following (Table III.) is a preliminary determination of $\mathrm{R}_{0}$, made merely to test the working of the apparatus. In this experiment ordinary ice and tap-water were used. The thermal regulator was not yet adjusted and the temperature of the coils was varying quite rapidly, yet the value of $R_{0}$ is almost identical with that obtained subsequently.

TABLE III.

Platinum Thermometer in Ice.

\begin{tabular}{|c|c|c|c|c|}
\hline $\begin{array}{l}\text { Time. } \\
\text { Mar. } 10, \\
1897 .\end{array}$ & Coils. & Bridge-Wire. & $\begin{array}{l}\text { Temperature } \\
\text { of Coils. }\end{array}$ & $R_{0}$ \\
\hline 4.10 & $\begin{array}{r}C, D, G, H=255 \\
\text { Coil cor. }-011\end{array}$ & $\begin{array}{c}\text { B.W. Reading }+3 \cdot 461 \\
\text { Cal. cor. } \ldots-.025 \\
\text { Zero cor. } \ldots-011\end{array}$ & $\begin{array}{c}20 \cdot 80 \\
\text { Temp. }+053 \\
\text { Cor. }\end{array}$ & $258 \cdot 467$ \\
\hline 4.20 & $\begin{array}{r}\mathrm{D}, \mathrm{D}, \mathrm{F} \ldots=260 \\
\text { Coil cor. }+.017\end{array}$ & $\begin{array}{l}\text { B.W. Reading }-1.608 \\
\text { Cal. cor. } \ldots+012 \\
\text { Zero ror. } \ldots-011\end{array}$ & $\begin{array}{c}20 \cdot 90 \\
\text { Temp. }+061 \\
\text { Cor. }+001\end{array}$ & $2.58 \cdot 171$ \\
\hline 4.23 & $\begin{array}{l}\text { C, } D, E, H=265 \\
\text { Coil cor. }+016\end{array}$ & $\begin{array}{l}\text { B.W. Reading }-6.643 \\
\text { Cal. cor. } \ldots+017 \\
\text { Zero cor. ... - } 011\end{array}$ & $\begin{array}{c}20 \cdot 90 \\
\text { Temp. }+.062 \\
\text { Cor. }\end{array}$ & $258 \cdot 471$ \\
\hline & & & Mean ... & $258-470$ \\
\hline
\end{tabular}

Determination of $R_{1}$. The resistance at $100^{\circ} \mathrm{C}, \mathrm{R}_{1}$, was determined in an hypsometer in which the thermometer was screened on all sides (by polished metal screens) from the effects of radiation. The hypsometer was provided with a small water manometer to indicate the excess of pressure within. To determine the atmospheric pressure, the barometer already described was used in connexion with the standard $\mathrm{B}$ and $\mathrm{D}$ scale. The temperature of the barometric column was taken by means of two Bender and Hobein thermomsters of normal glass, graduated to $\frac{1}{10} \mathrm{C}$., whose indications were reduced to the air-scale through a previous comparison with the platinum thermometer and a Tonnelot thermometer standardized at the Bureau International. The entire barometric column was wrapped to a thickness of several centimetres with asbestos paper and cotton to ensure 
Tarle IV.

Platinum Thermometer in Ice.

\begin{tabular}{|c|c|c|c|c|c|}
\hline Time. & Coils. & & Bridge-Wire. & $\begin{array}{c}\text { Temperature } \\
\text { of Coils. }\end{array}$ & $\mathbf{R}_{0}$ \\
\hline 12.20 & $\begin{array}{c}\mathrm{O}, \mathrm{D}, \mathrm{F}, \ldots \ldots \\
\text { Coil cor. } \ldots\end{array}$ & $\begin{array}{l}=260 \\
+\cdot 017\end{array}$ & $\begin{array}{l}\text { B.W. Readg. }-1.556 \\
\text { Cal. cor. } \quad+011 \\
\text { Zero cor. } \quad-.016\end{array}$ & $\begin{array}{c}20 \cdot 29 \\
\text { Temp. cor. }+\cdot 020\end{array}$ & $258 \cdot 476$ \\
\hline 12.27 & $\begin{array}{c}\mathrm{C}, \mathrm{D}, \mathrm{G}, \mathrm{H} \\
\text { Coil cor. } \ldots\end{array}$ & $\begin{array}{l}=255 \\
-011\end{array}$ & $\begin{array}{l}\text { B.W. Readg. }+3.506 \\
\text { Cal. cor. } \quad-.025 \\
\text { Zero cor. } \quad-.016\end{array}$ & $\begin{array}{c}20 \cdot 29 \\
\text { Temp. cor. }+.019\end{array}$ & $258 \cdot 473$ \\
\hline 12.32 & $\begin{array}{c}\mathrm{C}, \mathrm{D}, \mathrm{F}, \ldots \ldots \\
\text { Coil cor. } \ldots\end{array}$ & $\begin{array}{l}=260 \\
+\cdot 017\end{array}$ & $\begin{array}{ll}\text { B.W. Readg. }-1.558 \\
\text { Cal. cor. } & +.011 \\
\text { Zero cor. } & -.016\end{array}$ & $\begin{array}{c}20 \cdot 30 \\
\text { Temp. cor. }+.020\end{array}$ & $258 \cdot 474$ \\
\hline 12.40 & $\begin{array}{c}\mathrm{C}, \mathrm{D}, \mathrm{G}, \mathrm{H} \ldots \\
\text { Coil cor. } \ldots\end{array}$ & $\begin{array}{l}=255 \\
-.011\end{array}$ & $\begin{array}{l}\text { B.W. Readg. }+3503 \\
\text { Cal. cor. } \quad-025 \\
\text { Zero cor. } \quad-.016\end{array}$ & $\begin{array}{c}20 \cdot 33 \\
\text { Temp. cor. }+\cdot 022\end{array}$ & $258 \cdot 473$ \\
\hline 12.50 & $\begin{array}{r}\mathrm{C}, \mathrm{D}, \mathrm{F}, \mathrm{H} \ldots \\
\text { Coil cor. } \ldots\end{array}$ & $\begin{array}{l}=265 \\
+.016\end{array}$ & $\begin{array}{ll}\text { B.W. Readg. } & -6.600 \\
\text { Cal. cor. } & +046 \\
\text { Zero cor. } & -016\end{array}$ & $\begin{array}{c}20 \cdot 34 \\
\text { Temp. cor. }+\cdot 023\end{array}$ & $258 \cdot 470$ \\
\hline 12.55 & $\begin{array}{c}\mathrm{O}, \mathrm{D}, \mathrm{F} \\
\text { Coil cor....... }\end{array}$ & $\begin{array}{l}=260 \\
+\cdot 017\end{array}$ & $\begin{array}{cc}\text { B. W. Readg. }-1.563 \\
\text { Cal. cor. } \quad+.011 \\
\text { Zero cor. } \quad-016\end{array}$ & $\begin{array}{c}20 \cdot 35 \\
\text { Temp. cor. }+.024\end{array}$ & $258 \cdot 473$ \\
\hline 1.05 & $\begin{array}{l}\text { FI, C } \ldots \ldots \ldots . . . \\
\text { Coil cor. } \ldots\end{array}$ & $\begin{array}{l}=.260 \\
-.005\end{array}$ & $\begin{array}{lr}\text { B.W. Readg. }-1.544 \\
\text { Cal. cor. } \quad+011 \\
\text { Zero cor. } \quad-016\end{array}$ & $\begin{array}{c}20 \cdot 37 \\
\text { Temp. cor. }+\cdot 025\end{array}$ & $258 \cdot 471$ \\
\hline 1.15 & $\begin{array}{c}\text { FI, D, E, F, G, F } \\
\text { Coil cor. } \cdots\end{array}$ & $\begin{array}{r}\mathrm{H}=255 \\
+\cdot 179\end{array}$ & $\begin{array}{l}\text { B.W. Readg. }+3 \cdot 306 \\
\text { Cal. cor. }-\cdot 024 \\
\text { Zero cor. } \quad-016\end{array}$ & $\begin{array}{c}20 \cdot 38 \\
\text { Temp. cor. }+.025\end{array}$ & $258 \cdot 470$ \\
\hline 1.20 & $\begin{array}{c}\mathrm{C}, \mathrm{D}, \mathrm{E} \ldots . . . \\
\text { Coil cor. } \ldots\end{array}$ & $\begin{array}{l}=260 \\
+.017\end{array}$ & $\begin{array}{ll}\text { B.W. Readg. }-1.566 \\
\text { Cal, cor. } \quad+011 \\
\text { Zero col. } \quad-016\end{array}$ & $\begin{array}{c}20 \cdot 39 \\
\text { Temp. cor. }+\cdot 026\end{array}$ & $258 \cdot 472$ \\
\hline \multicolumn{5}{|c|}{ Mean ................. } & 258.472 \\
\hline
\end{tabular}

Note.- In this determination of $\mathrm{R}_{0}$ a double-wall vessel was used, with ice in both inner and outer compartments. Outer vessel wrapped with heary boiler-felt.

uniformity of temperature. The thermometers were inserted between the wrappings touching the glass of the barometer. The temperature of the standard scale was taken by another similar thermometer. A series of measurements of the barometric height were made by one observer while the other 
Comparisons of Mercury and Platinum Thermometers. 17

TABLE V.

Platinum Thermometer in Ice.

\begin{tabular}{|c|c|c|c|c|}
\hline $\begin{array}{l}\text { Time. } \\
\text { May } 6 .\end{array}$ & Coils. & Bridge-Wire. & $\begin{array}{l}\text { 'Temperature } \\
\text { of Coils. }\end{array}$ & $\mathbf{R}_{0}$ \\
\hline 3.45 & $\begin{array}{r}\mathrm{O}, \mathrm{D}, \mathrm{F}, \mathrm{H} \ldots=265 \\
\text { Coil cor. } \ldots+.016\end{array}$ & $\begin{array}{cc}\text { B.W. Readg. } & -6 \cdot 589 \\
\text { Cal. cor. } & +.047 \\
\text { Zero cor. } & -003\end{array}$ & $\begin{array}{c}19 \\
19.94 \\
\text { Temp. cor. }-.004\end{array}$ & $258 \cdot 467$ \\
\hline 3.55 & $\begin{aligned} \mathrm{O}, \mathrm{D}, \mathrm{G}, \mathrm{H} \ldots & =255 \\
\text { Coil cor. ... } & =.011\end{aligned}$ & $\begin{array}{lr}\text { B.W. Readg. } & +3.515 \\
\text { Cal. cor. } & -.025 \\
\text { Zero cor. } & -.003\end{array}$ & $\begin{array}{c}19 \cdot 90 \\
\text { Temp. cor. }-\cdot 006\end{array}$ & $258 \cdot 470$ \\
\hline 4.00 & $\begin{array}{r}\mathrm{C}, \mathrm{D}, \mathrm{F}, \mathrm{H} \ldots=265 \\
\text { Coil cor. } \ldots+016\end{array}$ & $\begin{array}{cc}\text { B.W. Readg. } & -6.588 \\
\text { Cal. cor. } & +.047 \\
\text { Zero cor. } & -003\end{array}$ & $\begin{array}{r}19 \cdot 90 \\
\text { Temp. cor. }-\cdot 007\end{array}$ & $258 \cdot 468$ \\
\hline 4.05 & $\begin{array}{r}\mathrm{O}, \mathrm{D}, \mathrm{F} \ldots \ldots=260 \\
\text { Coil cor. ... }\end{array}$ & $\begin{array}{cc}\text { B.W. Readg. } & -1.550 \\
\text { Cal, cor. } & +.011 \\
\text { Zero cor. } & -.003\end{array}$ & $\begin{array}{c}19 \cdot 91 \\
\text { Temp. cor. }-.005\end{array}$ & 258.470 \\
\hline 4.12 & 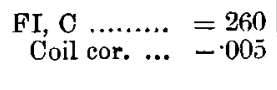 & $\begin{array}{cc}\text { B. W. Readg. } & -1.527 \\
\text { Cal. cor. } & +.011 \\
\text { Zero cor. } & -.003\end{array}$ & $\begin{array}{c}19.92 \\
\text { Temp. cor. }-.005\end{array}$ & $258 \cdot 471$ \\
\hline 4.20 & $\begin{array}{r}\text { FI, D, E, F,G,H }=255 \\
\text { Coil cor. } \ldots+179\end{array}$ & $\begin{array}{cc}\text { B.W. Readg. } & +3.323 \\
\text { Cal. cor. } & -.024 \\
\text { Zero cor. } & -.003\end{array}$ & $\begin{array}{r}19.93 \\
\text { Temp. cor. }-.005\end{array}$ & $258 \cdot 470$ \\
\hline 4.28 & $\begin{array}{r}\mathrm{C}, \mathrm{D}, \mathrm{F} \ldots \ldots=260 \\
\text { Coil cor. ... }+017\end{array}$ & $\begin{array}{cc}\text { B.W. Readg. } & -1.550 \\
\text { Cal. cor. } & +.011 \\
\text { Zero cor. } & -.003\end{array}$ & $\begin{array}{c}19.94 \\
\text { Temp. cor. }-.001\end{array}$ & 258.471 \\
\hline 4.40 & $\begin{array}{r}0, D, F \ldots \ldots=260 \\
\text { Coil cor. ... }+017\end{array}$ & $\begin{array}{ll}\text { B. W. Readg. } & -1552 \\
\text { Cal. cor. } & +.011 \\
\text { Zero cor. } & -.003\end{array}$ & $\begin{array}{c}19 \cdot 90 \\
\text { Temp, cor. }-.006\end{array}$ & 258.467 \\
\hline \multicolumn{4}{|c|}{ Mean } & $258 \cdot 469$ \\
\hline
\end{tabular}

In this determination a double-wall vessel wrapped in felt was again used.

observer measured the resistance of the platinum thermometer in steam, with different combinations of coils and bridgewire. A time-chart of the barometric pressure served to give the pressure at the instant when the resistance was taken. Usually the observations of the barometric height were taken simultaneously, as nearly as possible, with the resistance of the platinum thermometer, for the variations of the atmospheric pressure seem to take place suddenly, and not uniformly as

Phil. Mag. S. 5. Vol. 48. No. 290. July 1894. 
TABLE VI.

Platinum Thermometer in Ice.

\begin{tabular}{|c|c|c|c|c|}
\hline $\begin{array}{l}\text { Time. } \\
\text { May } 6 .\end{array}$ & Coils. & Bridge-Wire. & $\begin{array}{c}\text { Temperature } \\
\text { of Coils. }\end{array}$ & $\mathbf{R}_{0}$ \\
\hline 5.00 & $\begin{array}{r}\mathrm{C}, \mathrm{D}, \mathrm{F}, \mathrm{H} \ldots=265 \\
\text { Coil cor. } \ldots+.016\end{array}$ & $\begin{array}{cc}\text { B.W. Readg. } & -6589 \\
\text { Cal. cor. } & +047 \\
\text { Zero cor. } & -003\end{array}$ & $\begin{array}{c}10.97 \\
\text { Temp. cor. }-002\end{array}$ & 258.469 \\
\hline 5.10 & $\begin{array}{r}\mathrm{C}, \mathrm{D}, \mathrm{F} \ldots \ldots=260 \\
\text { Coil cor. } \ldots .+017\end{array}$ & $\begin{array}{lr}\text { B.W. Readg. } & -1.554 \\
\text { Cal. cor. } & +.011 \\
\text { Zero tor. } & -.003\end{array}$ & $\begin{array}{c}19.97 \\
\text { Temp. cor. }-.002\end{array}$ & $258 \cdot 469$ \\
\hline 5.15 & $\begin{aligned} \mathrm{C}, \mathrm{D}, \mathrm{G}, \mathrm{H} \ldots & =255 \\
\text { Coil cor. } \ldots & =.011\end{aligned}$ & $\begin{array}{cc}\text { B.W. Readg. } & +3 \cdot 509 \\
\text { Oal. cor. } & -.025 \\
\text { Zero cor. } & -.003\end{array}$ & Temp. cor. -.002 & $258 \cdot 468$ \\
\hline 5.20 & $\begin{array}{r}\text { FI, } \mathrm{C} \ldots \ldots . . .=260 \\
\text { Coil cor. } \ldots=.005\end{array}$ & $\begin{array}{cc}\text { B.W. Readg. } & -1.527 \\
\text { Cal. cor. } & +.011 \\
\text { Zero cor. } & -.003\end{array}$ & Temp. cor. $-19 \cdot 98$ & 258.475 \\
\hline 5.24 & $\begin{array}{r}\text { FI,D,E, }, \mathrm{G}, \mathrm{G}, \mathrm{H}=255 \\
\text { Coil cor. } \ldots+\cdot 179\end{array}$ & $\begin{array}{cc}\text { B W. Readg. } & +3.320 \\
\text { Cal. cor. } & -.024 \\
\text { Zero cor. } & -.003\end{array}$ & $\begin{array}{c}19.98 \\
\text { Temp. cor. }-001\end{array}$ & 258.471 \\
\hline 5.29 & $\begin{array}{r}\text { FI, } \mathbf{C} \ldots \ldots \ldots=260 \\
\text { Coil cor. ... }\end{array}$ & $\begin{array}{cr}\text { B.W. Readg. } & -1.527 \\
\text { Cal. cor. } & +.011 \\
\text { Zero cor. } & -.003\end{array}$ & $\begin{array}{c}19.99 \\
\text { Temp. cor. }-001\end{array}$ & $258 \cdot 475$ \\
\hline 5.35 & $\begin{array}{r}\mathrm{C}, \mathrm{D}, \mathrm{F} \ldots \ldots=260 \\
\text { Coil cor. ... }\end{array}$ & $\begin{array}{ll}\text { B.W. Readg. } & -1.550 \\
\text { Cal. cor. } & +.011 \\
\text { Zero cor. } & -.003\end{array}$ & Temp. cor. $\quad \cdot 000$ & $258 \cdot 473$ \\
\hline \multicolumn{4}{|c|}{ Mean } & $258+71$ \\
\hline
\end{tabular}

This determination of $\mathbf{R}_{0}$ was made immediately after the preceding, the inner nickel-plated calorimeter being first removed. The same freezing-mixture was used, and the contacts of the platinum thermometer had not been touched.

indicated by a time-chart. Moreover, the platinum thermometer seemed to respond to the changes more rapidly than the barometer, which appeared to have an appreciable lag.

The observed barometric height, corrected for temperature and errors of graduation of the standard metre-bar, was reduced to $0^{\circ} \mathrm{C}$., latitude $45^{\circ}$, sea-level. From the reduced barometric height the temperature of the steam was obtained by interpolation in Broch's tables of the pressure of aqueous vapour, recalculated from Regnault's experiments ('Trav. et Mém. du Bur. Int. des Poids et Mes. t. i.). 
From the observed resistance of the platinum thermometer and the corresponding temperature of the steam, the resistance $R_{1}$ at $100^{\circ} \mathrm{C}$. was deduced as follows:-

For example, from the first observation in the following table (VII.) we have

$\{$ Resistance $\mathbf{R}=358.053$ mean box-units (Box No. 7).

$\{$ Red. barometric ht. $=755 \cdot 19 \mathrm{~mm}$.

Corresponding temperature, $t$, of steam, obtained from Broch's tables $=99^{\circ} \cdot 822$.

The correction, $d t / d p$, to be applied to the air temperature, $t$, of the boiling-point of water to reduce to the boiling-point at $760 \mathrm{~mm}$. of mercury at $0^{\circ} \mathrm{C}$., latitude $45^{\circ}$, sea-level, is therefore $0^{\circ} .0368$ per min. of mercury.

To find the corresponding correction to be applied to the platinum temperature we have

$$
t-p t=\delta\left\{\left(\frac{t}{100}\right)^{2}-\frac{t}{100}\right\}
$$

differentiating

$$
\frac{d \cdot p t}{d p}=\frac{d \cdot p t}{d t} \frac{d t}{d p}=\cdot 0368\left\{1-\delta \frac{2 t-100}{10000}\right\} .
$$

We may assume an approximate value of $\delta=1.50$ (from a previous knowledge of the constants of platinum thermometers) as sufficiently accurate for the purpose of this reduction.

If it happens that the values of $\delta$ assumed differ greatly from the final value obtained from the standardization, it may be necessary to substitute this new value of $\delta$; we have then

$$
\frac{d p t}{d p}=0^{\circ} 0362 \text { per mm. of mercury. }
$$

From the equation defining platinum temperature,

we have

$$
p t=\frac{\mathrm{R}-\mathrm{R}_{0}}{\mathrm{R}_{1}-\mathrm{R}_{0}} \times 100,
$$

$$
\mathrm{R}_{1}=\mathrm{R}_{0}+\frac{100}{p t}\left(\mathrm{R}-\mathrm{R}_{0}\right) .
$$

Reducing $t=99^{\circ} .822$ to the corresponding temperature on the platinum scale, we have $p t=99^{\circ} .826$.

Hence

$$
\begin{aligned}
\mathbf{R}_{1} & =258 \cdot 471+100 \frac{(358 \cdot 053-258 \cdot 471)}{99 \cdot 826} \\
& =358 \cdot 227 \text { mean box-units. }
\end{aligned}
$$


TABLE VIJ.-Platinum Thermometer in Steam.

\begin{tabular}{|c|c|c|c|c|c|c|}
\hline Time. & Coils. & Bridge-Wire. & $\begin{array}{l}\text { Temp. } \\
\text { of } \\
\text { Coils. }\end{array}$ & $\begin{array}{l}\text { Barom. } \\
\text { pressure } \\
\text { rediced } \\
\text { to } 0^{\circ} \mathrm{C} \text {., } \\
\text { sea-level, } \\
\text { lat. } 45^{\circ} .\end{array}$ & $\begin{array}{l}\text { Results } \\
\text { at obs. } \\
\text { pres. }\end{array}$ & $\mathbf{R}_{100^{\circ}}$ \\
\hline $\begin{array}{c}\text { May } 4 . \\
2.37\end{array}$ & $\begin{array}{c}\mathrm{B}, \mathrm{E} \\
\text { Coil cor. } \ldots . . . .+1.0360 \\
\end{array}$ & $\begin{array}{lr}\text { B.W. Readg. } & -1.976 \\
\text { Cal. cor. } & +014 \\
\text { Zero cor. } & -.003\end{array}$ & $\begin{array}{l}1973 \\
-025\end{array}$ & ) & 358.053 & $358 \cdot 227$ \\
\hline 246 & $\begin{array}{c}\text { B, F, } \mathbf{G}, \mathrm{H} \ldots=355 \\
\text { Coil cor. } \ldots=\cdot 003\end{array}$ & $\begin{array}{lr}\text { B.W. Readg. } & +3 \cdot 103 \\
\text { Cal. cor. } & -\cdot 023 \\
\text { Zero cor. } & -.003\end{array}$ & $\begin{array}{l}19 \cdot 75 \\
-\cdot 023\end{array}$ & & 358.052 & $358 \cdot 226$ \\
\hline 3.08 & $\begin{array}{c}\text { FI, } C, D, F \ldots=360 \\
\text { Coil cor. } \ldots+054\end{array}$ & $\begin{array}{lr}\text { B.W. Readg. } & -1.993 \\
\text { Cal. cor. } & +014 \\
\text { Zero cor. } & -.003\end{array}$ & $\begin{array}{l}19 \cdot 79 \\
-.020\end{array}$ & 75519 & $358 \cdot 052$ & $358 \cdot 226$ \\
\hline 3.20 & $\begin{array}{r}\text { B, } \mathbf{E} \quad \ldots \ldots \ldots=360 \\
\text { Coil cor. } \quad \ldots+043\end{array}$ & $\begin{array}{lr}\text { B.W. Readg. } & -1.982 \\
\text { Oal. cor. } & +.014 \\
\text { Zero cor. } & -.003\end{array}$ & $\begin{array}{l}19 \cdot 80 \\
-\cdot 019\end{array}$ & & $358 \cdot 053$ & $358 \cdot 227$ \\
\hline 3.34 & $\begin{array}{l}\mathrm{FI}, \mathrm{C}, \mathrm{G}, \mathrm{D}, \mathrm{H}=355 \\
\text { Coil cor. } \quad \ldots+026\end{array}$ & $\begin{array}{cc}\text { B.W. Readg. } & +3 \cdot 080 \\
\text { Cal. cor. } & -\cdot 222 \\
\text { Zero cor. } & -.003\end{array}$ & $\begin{array}{l}19 \cdot 80 \\
-.019\end{array}$ & $755 \cdot 32$ & $358.062 \mid$ & 358.232 \\
\hline $\begin{array}{l}\text { May } 7 . \\
12.17\end{array}$ & $\begin{array}{r}\text { B, E } \quad \ldots \ldots \ldots=360 \\
\text { Cuil cor. } \ldots . . .043\end{array}$ & $\begin{array}{lr}\text { B.W. Readg. } & -1.864 \\
\text { Cal cor. } & +014 \\
\text { Zero cor. } & -.003\end{array}$ & $\begin{array}{l}20.00 \\
\cdot 000\end{array}$ & & $358 \cdot 190$ & 358.228 \\
\hline 12.25 & $\begin{array}{c}\mathrm{B}, \mathrm{F}, \mathrm{G}, \mathrm{H} \ldots=355 \\
\text { Coil cor. } \ldots=\cdot 003\end{array}$ & $\begin{array}{lr}\text { B.W. Readg. } & +3 \cdot 220 \\
\text { Cal. cor. } & -023 \\
\text { Zero cor. } & -.003\end{array}$ & $\begin{array}{l}20 \cdot 01 \\
+\cdot 001\end{array}$ & 758.95 & $358 \cdot 192$ & $3: 8 \cdot 230$ \\
\hline 12.34 & $\begin{array}{c}\mathrm{B}, \mathrm{E}, \mathrm{H} \ldots \ldots=365 \\
\text { Coil cor. } \ldots . . .+042\end{array}$ & $\begin{array}{lr}\text { B.W. Readg. } & -6.900 \\
\text { Cal. cor. } & +.049 \\
\text { Zero cor. } & -.003\end{array}$ & $\begin{array}{l}20 \cdot 02 \\
+\cdot 002\end{array}$ & & $358 \cdot 192$ & $358 \cdot 230$ \\
\hline May 7. & $\begin{array}{c}\mathrm{B}, \mathrm{E} \\
\text { Coil cor...... } \ldots=360 \\
\end{array}$ & $\begin{array}{lr}\text { B.W. Readg. } & -1 \cdot 876 \\
\text { Cal. cor. } & +.014 \\
\text { Zero cor. } & -.003\end{array}$ & $\begin{array}{l}20 \cdot 35 \\
+\cdot 033\end{array}$ & $759 \cdot 36$ & 358.211 & 358.235 \\
\hline 4.05 & $\begin{array}{r}\mathrm{B}, \mathrm{F}, \mathrm{G}, \mathrm{H} \ldots=355 \\
\text { Coil cor. } \ldots=\cdot 003\end{array}$ & $\begin{array}{cr}\text { B.W. Readg. } & +3 \cdot 214 \\
\text { Cal. cor. } & -\cdot 022 \\
\text { Zero cor. } & -.003\end{array}$ & $\begin{array}{l}2036 \\
+033\end{array}$ & & $358 \cdot 219$ & 358.236 \\
\hline 4.15 & 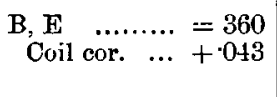 & $\begin{array}{lr}\text { B.W. Readg. } & -1870 \\
\text { Cal. cor. } & +.014 \\
\text { Zero cor. } & -003\end{array}$ & $\begin{array}{l}20 \cdot 37 \\
+\cdot 035\end{array}$ & 759.54 & $358 \cdot 219$ & $358 \cdot 236$ \\
\hline 4.18 & $\begin{array}{c}\mathrm{B}, \mathrm{E} \\
\mathrm{Coil} \text { cor. } \ldots . . .\end{array}$ & $\begin{array}{lr}\text { B.W. Readg. } & -1.870 \\
\text { Cal. cor. } & +.014 \\
\text { Zero cor. } & -003\end{array}$ & $\begin{array}{l}20.37 \\
+.035\end{array}$ & & $358 \cdot 219$ & $358 \cdot 23 i$ \\
\hline
\end{tabular}

$\therefore R_{1}=358 \cdot 231$ mean box-units (Box No. 7 ). 
From the preceding observations we have :-

$\mathrm{R}_{0}=258.471$ (meau box-units, at $20^{\circ} \mathrm{C}$., of box No. 7),

$\mathrm{R}_{1}=358 \cdot 231$

$"$

,

,

,

This gives

$$
\frac{\mathrm{R}_{1}}{\mathrm{R}_{0}}=1 \cdot 385962 .
$$

Mr. E. H. Griffiths was kind enongh to standardize this thermometer with great care before sending it, and the values found by him (as a mean of many observations with different combinations of coils and bridge-wire of Box No.6) were :-

January 21, 1896.

$$
\begin{aligned}
\mathrm{R}_{1} & =358.075 \text { mean box-units Box } 6, \\
\mathrm{R}_{0} & =258.366 \quad, \quad ", " \text { " } " \\
\mathrm{Pt}_{\text {sulphur }} & =422.54 \text { (barometer at } 771.35 \mathrm{~mm} .) \text { : }
\end{aligned}
$$

hence

$$
\delta=1 \cdot 490 .
$$

"In this determination the average temperature of the box was about $15^{\circ} \cdot 4$, but it was rapidly varying. Moreover, the temperature correction was very large, the box being right at $20^{\circ} \mathrm{C} . "$

January 23, 1896.

$$
\begin{aligned}
& \mathrm{R}_{1}=258 \cdot 362, \\
& \mathrm{R}_{0}=358 \cdot 078, \\
& \mathrm{R}_{s}=679 \cdot 510 \text { (barometer at } 769 \cdot 20 \text { ). }
\end{aligned}
$$

Hence

$$
\begin{aligned}
\frac{\mathrm{R}_{1}}{\mathrm{R}_{0}} & =1 \cdot 38596, \\
\delta & =1 \cdot 491 .
\end{aligned}
$$

The remarkable agreement of our value of $\frac{R_{1}}{\bar{R}_{0}}$ with that found by Griffiths renders it unnecessary for us to determine the resistance of the thermometer in boiling sulphur (the third temperature usually employed), and we therefore accepted the value of $\delta, 1.491$, given by Griffiths, as correct.

[It is interesting to note that for the standardization given under date of January 21, the value of

$$
p t=-\frac{\mathrm{R}_{0}}{\mathrm{R}_{1}-\mathrm{R}_{0}} \times 100=-259^{\circ} \cdot 12,
$$


which corresponds to zero resistance of the platinum thermometer, gives for the absolute zero [by using $\delta=1.490$ in $\left.t-p t=\delta\left\{(t / 100)^{2}-t / 100\right\}\right]-274^{\circ} \cdot 44$. Similarly the standardization of January 23 gives the absolute zero $-274^{\circ} \cdot 41$.]

\section{Standardization of Platinum Thermometer.}

The details of the elaborate comparisons by Mr. Griffiths, on which the constant, $\delta$, of this thermometer is based, are given below (Tables VIII., IX., X.). 'The resistance-box (No.6) used in this standardization was similar to the one described in ' Nature,' Nov. 14, 1895.

"For all purposes of comparison between the results obtained here and in Baltimore, we only require the values of $\frac{R_{1}}{R_{0}}$ and $\delta$, the magnitude of the unit used being of no consequence. I, however, give the observations in full, to show the probable order of accuracy."

\section{January 21, 1896.}

"On the above date a preliminary series of observations was made in ice, steam, and sulphur-vapour. The observations, however, were hurried, the resistance-box was not contained in its tank, and its temperature was about $15^{\circ} .50 \mathrm{C}$. Thus the temperature correction was large. I did not regard the work as anything but preliminary, and will therefore only give results (the resistances are corrected for temperature of box, \&c.) :-

$$
\begin{aligned}
& \mathrm{R}^{\prime}=358 \cdot 480 \text { when barometer }{ }^{*}=771 \cdot 24, \\
& \mathrm{R}_{0}=258 \cdot 366, \\
& \mathrm{R}_{s}=679 \cdot 680 \text { when barometer }=771 \cdot 35 .
\end{aligned}
$$

Hence we get

$$
\begin{aligned}
& \mathrm{R}_{1}=358.075 \\
& \mathrm{R}_{0}=258.366 \\
& \hline \mathrm{Fl}=99709
\end{aligned}
$$

$$
\begin{aligned}
\frac{\mathrm{R}_{1}}{\overline{\mathrm{R}}_{0}} & =1.38592 \\
\delta & =1 \cdot 490
\end{aligned}
$$

* The barometer is in each case corrected for temperature, scale errors, and for value of $y$ to sea-level, latitude $45^{\circ}$. 
Comparisons of Mercury and Platinum Thermometers. 23 TABLE VIII.

Platinum Thermometer in Ice.

\begin{tabular}{|c|c|c|c|c|}
\hline $\begin{array}{l}\text { Time. } \\
\text { Jan. 23. }\end{array}$ & Coils. & $\begin{array}{l}\text { Bridge-Wire } \\
\text { Reading. }\end{array}$ & $\begin{array}{c}\text { Temperature } \\
\text { of Coils. }\end{array}$ & $\begin{array}{c}R_{0} . \\
(\text { Box } \\
\text { No. 6.) }\end{array}$ \\
\hline 5.19 & $\begin{array}{r}\mathrm{C}, \mathrm{D}, \mathrm{F}, \mathrm{H} \ldots=265 \\
\text { Coil cor. } \ldots=-102\end{array}$ & $\begin{array}{cc}\text { B.W. Readg. } & -6.602 \\
\text { Cal. cor. } & +109 \\
\text { Zero cor. } & -.078\end{array}$ & Cor. $\stackrel{20.50}{+.034}$ & $258 \cdot 361$ \\
\hline 5.21 & , & $\begin{array}{lr}\text { B.W. Readg. } & -6.600 \\
\text { Cal. cor. } & +\cdot 109 \\
\text { Zero cor. } & -.078\end{array}$ & " & $258 \cdot 363$ \\
\hline 5.21 & $"$ & $\begin{array}{lr}\text { B.W. Readg. } & -6601 \\
\text { Oal. cor. } & +\cdot 109 \\
\text { Zero cor. } & -.078\end{array}$ & $"$ & $258 \cdot 362$ \\
\hline 5.27 & $\begin{array}{ll}C, D, F & \ldots=260 \\
\text { Coil cor. } & \ldots=094\end{array}$ & $\begin{array}{cr}\text { B.W. Readg. } & -1.526 \\
\text { Cal. cor. } & +026 \\
\text { Zero cor. } & -.078\end{array}$ & $"$ & $258 \cdot 362$ \\
\hline 5.28 & $"$ & $\begin{array}{lr}\text { R.W. Readg. } & -1.524 \\
\text { Cal. cor. } & +.026 \\
\text { Zero cor. } \quad-.078\end{array}$ & ", & $258: 364$ \\
\hline 5.30 & $\begin{array}{c}\mathrm{C}, \mathrm{D}, \mathrm{G}, \mathrm{H} \ldots=255 \\
\text { Coil cor. } \ldots=.078\end{array}$ & $\begin{array}{cr}\text { B.W. Readg. } & +3546 \\
\text { Cal. cor. } & -060 \\
\text { Zero cor. } & -078\end{array}$ & $"$ & $258 \cdot 364$ \\
\hline 5.32 & ", & $\begin{array}{lr}\text { B.W. Readg. } & +3.545 \\
\text { Ual. cor. } & -.060 \\
\text { Zero cor. } & -.078\end{array}$ & " & $258 \cdot 363$ \\
\hline 5.35 & $\begin{array}{r}\mathrm{C}, \mathrm{D}, \mathrm{G} \ldots \ldots=250 \\
\text { Coil cor. } \ldots . .079\end{array}$ & $\begin{array}{lr}\text { B.W. Readg. } & +8 \cdot 626 \\
\text { Cal. cor. } & =\cdot 144 \\
\text { Zero cor. } & -\cdot 078\end{array}$ & $"$ & $258 \cdot 359$ \\
\hline 5.37 & $"$ & $\begin{array}{ll}\text { B.W. Readg. } & +8 \cdot 627 \\
\text { Cul. cor. } & -\cdot 144 \\
\text { Zero cor. } & -.078\end{array}$ & $"$ & $258 \cdot 360$ \\
\hline \multicolumn{4}{|c|}{ 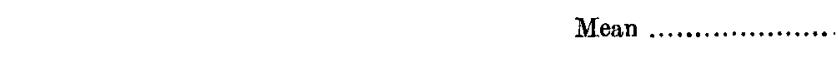 } & $258 \cdot 362$ \\
\hline
\end{tabular}

Determination of $\mathbf{R}_{1}, \mathbf{R}_{0}$, and $\mathbf{F I}$.

"We have

$\mathbf{R}^{\prime}=358 \cdot 416$ when bar. $=769 \cdot 39, \therefore$ b.p. $=100^{\circ} \cdot 344$,

$\mathrm{R}=258 \cdot 362$

$R^{\prime}-\overline{R_{0}=100 \cdot 054}$ for dif. in temp. $=100^{\circ} \cdot 344$. 
'Table IX.

Platinum Thermometer in Steam.

\begin{tabular}{|c|c|c|c|c|c|}
\hline $\begin{array}{l}\text { Time. } \\
\text { Jan. } 23 .\end{array}$ & Coils. & $\begin{array}{c}\text { Bridge-Wire } \\
\text { Reading. }\end{array}$ & $\begin{array}{l}\text { Temperature } \\
\text { of Coils. }\end{array}$ & $\begin{array}{c}\text { Baro- } \\
\text { meter } \\
\text { (corr.). }\end{array}$ & $\begin{array}{c}R^{\prime} . \\
(\text { Box } \\
\text { No. } 6 .)\end{array}$ \\
\hline 4.36 & $\begin{array}{c}\mathrm{C}, \mathrm{D}, \mathrm{F}, \mathrm{I}, \mathrm{FI}=365 \\
\text { Coil cor. } \ldots=\cdot 179\end{array}$ & $\begin{array}{cc}\text { B.W. Readg. } & -6 \cdot 466 \\
\text { Gal. cor. } & +.106 \\
\text { Zero cor. } & -.078\end{array}$ & $\begin{array}{c}\stackrel{9}{20} 32 \\
\text { Cor. }+\cdot 030\end{array}$ & $\underset{769 \cdot 40}{\operatorname{mm}}$ & $358 \cdot 413$ \\
\hline 4.43 & " & $\begin{array}{cc}\text { B.W. Readg. } & -6.469 \\
\text { Cal. cor. } & +\cdot 106 \\
\text { Zero cor. } & -078\end{array}$ & $\begin{array}{ll} & 20 \cdot 38 \\
\text { Cor. } & +\cdot 035\end{array}$ & $"$ & $358 \cdot 415$ \\
\hline 4.46 & $\begin{array}{cc}\mathrm{C}, \mathrm{D}, \mathrm{F}, \mathrm{FI} & =360 \\
\text { Coil cor. } \ldots & -171\end{array}$ & $\begin{array}{lr}\text { B.W. Readg. } & -1.394 \\
\text { Cal. cor. } & +023 \\
\text { Zero cor. } & -078\end{array}$ & $\begin{array}{ll} & 20 \cdot 40 \\
\text { Cor. } & +\cdot 037\end{array}$ & $"$ & $358 \cdot 417$ \\
\hline 4.51 & $"$ & $\begin{array}{cc}\text { B.W. Readg. } & -1.397 \\
\text { Cal. cor. } & +.023 \\
\text { Zero cor. } & -.078\end{array}$ & Cor. $\begin{array}{c}20^{\circ} 42 \\
+.039\end{array}$ & $769 \cdot 45 \mid$ & $358 \cdot 416$ \\
\hline 4.55 & $\begin{array}{c}\text { C, } D, G, H, F I=355 \\
\text { Goil cor. } \cdots=\cdot 164\end{array}$ & 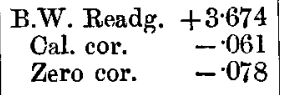 & $\begin{array}{ll} & 20 \cdot 45 \\
\text { Cor. } & +\cdot 042\end{array}$ & $"$ & $358 \cdot 413$ \\
\hline 4.59 & $"$ & $\begin{array}{lr}\text { B.W. Readg. } & +3676 \\
\text { Oal. cor. } & -061 \\
\text { Zero cor. } & -078\end{array}$ & Cor. $\begin{array}{l}20 \cdot 47 \\
+044\end{array}$ & $769 \cdot 40$ & $358 \cdot 417$ \\
\hline 5.6 & $\begin{aligned} \mathrm{O}, \mathrm{D}, \mathrm{G}, \mathrm{FI} & =350 \\
\text { Coil cor. } \ldots & -156\end{aligned}$ & $\left|\begin{array}{cc}\text { B.W. Readg. } & +8 \cdot 752 \\
\text { Cal. cor. } & -\cdot 146 \\
\text { Zero cor. } & -.078\end{array}\right|$ & $\begin{array}{ll} & 20 \cdot 49 \\
\text { Cor. } & +\cdot 046\end{array}$ & $769 \cdot 35$ & $358 \cdot 418$ \\
\hline 5.9 & $"$ & $\begin{array}{cr}\text { B.W. Readg. } & +8.750 \\
\text { Cal. cor. } & -.146 \\
\text { Zero cor. } & -.078\end{array}$ & Cor. $\begin{array}{l}20.49 \\
+.046\end{array}$ & $769 \cdot 30$ & $358 \cdot 416$ \\
\hline \multicolumn{4}{|c|}{ Mean .. } & $769 \cdot 39$ & $358 \cdot 416$ \\
\hline
\end{tabular}

$\mathrm{R}^{\prime}=358.416$ mean box-units (Box No. 6 ) when the barometer is $769.39 \mathrm{~mm}$.

"Hence mean $\frac{\delta \mathrm{R}}{\delta t}=0.99711$.

"Now $\frac{\delta p t}{\delta t}$ at $100^{\circ}=0.985$.

$\therefore \delta \mathrm{R}^{\prime}$ at $100^{\circ}=.9971 \times .985=\cdot 0.9821$,

$\therefore \delta \mathrm{R}^{\prime}$ for $0^{\circ} \cdot 344=\cdot 9821 \times \cdot 344=0.338$,

$\therefore \mathrm{R}_{1}=358 \cdot 416-0 \cdot 338=358 \cdot 078$. 


\section{TABLE X.}

Platinum Thermometer in Sulphur Vapour.

In sulphur vapour all the precautions must be taken which are mentioned on pp. 144-147, Phil. Trans. Roy. Soe., A, 1891, vol. elxxxii.

\begin{tabular}{|c|c|c|c|c|c|c|}
\hline $\begin{array}{l}\text { Time. } \\
\text { Jan. } 23 .\end{array}$ & Coils. & \multicolumn{2}{|c|}{$\begin{array}{l}\text { Blidge-Wire } \\
\text { Reading. }\end{array}$} & $\begin{array}{l}\text { Temperature } \\
\text { of Coils. }\end{array}$ & \multirow{2}{*}{$\frac{\begin{array}{c}\text { Baro- } \\
\text { meter } \\
\text { (corr.). }\end{array}}{\min _{769 \cdot 20}}$} & \multirow{2}{*}{ 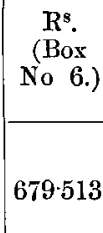 } \\
\hline 6.15 & $\begin{array}{r}\mathrm{A}, \mathrm{E} \\
\text { Coil cor. } \ldots . . .\end{array}$ & $\begin{array}{l}\text { B.W. Readg. } \\
\text { Cal cor. } \\
\text { Zero cor. }\end{array}$ & $\begin{array}{l}-.675 \\
+.009 \\
-.078\end{array}$ & 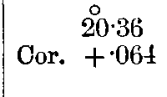 & & \\
\hline 6.18 & ", & $\begin{array}{l}\text { B.W. Readg. } \\
\text { Cal. cor. } \\
\text { Zero cor. }\end{array}$ & $\begin{array}{l}-.671 \\
+.009 \\
-.078\end{array}$ & $\begin{array}{l}20.35 \\
\text { Cor. }+.0622\end{array}$ & " & 679.515 \\
\hline 6.21 & $"$ & $\begin{array}{l}\text { B.W. Readg. } \\
\text { Cal. cor. } \\
\text { Zero cor. }\end{array}$ & $\begin{array}{l}-.672 \\
+.009 \\
-.078\end{array}$ & " & " & 679514 \\
\hline 6.25 & $\begin{array}{c}\text { A, } \mathbf{E}, \mathbf{H} \ldots \ldots=685 \\
\text { Coil. cor. } \ldots+185\end{array}$ & $\begin{array}{l}\text { B.W. Readg. } \\
\text { Cal. cor. } \\
\text { Zero cor. }\end{array}$ & $\begin{array}{r}-5.754 \\
+.095 \\
-.078\end{array}$ & $"$ & $769 \cdot 15$ & 679.510 \\
\hline 6.26 & $"$ & $\begin{array}{l}\text { B.W. Readg. } \\
\text { Cal, cor. } \\
\text { Zero cor. }\end{array}$ & $\begin{array}{r}-5.755 \\
+.095 \\
-078\end{array}$ & " & $769 \cdot 20$ & $679 \cdot 509$ \\
\hline 6.30 & $\begin{array}{r}\text { A, } \mathbf{F}, \mathrm{G}, \mathrm{H} \ldots=675 \\
\text { Coil cor. } \ldots+068\end{array}$ & $\begin{array}{l}\text { B.W. Readg. } \\
\text { Cal. cor. } \\
\text { Zero cor. }\end{array}$ & $\begin{array}{r}+4.527 \\
-.076 \\
-.078\end{array}$ & $"$ & $"$ & $679 \cdot 503$ \\
\hline 6.32 & $"$ & $\begin{array}{l}\text { B.W. Readg. } \\
\text { Cal. cor. } \\
\text { Zero cor. }\end{array}$ & $\begin{array}{r}+4.528 \\
-.076 \\
-.078\end{array}$ & $"$ & 769.25 & 679.504 \\
\hline & & & Mean & & $769 \cdot 20$ & 679.510 \\
\hline
\end{tabular}

$\mathrm{R}^{8}=679 \cdot 510$ mean box-units (Box No. 6) when barometer $=769 \cdot 20 \mathrm{~mm}$.

$$
\text { "Hence } \begin{aligned}
\mathrm{R}_{1} & =358 \cdot 078 \\
\mathrm{R}_{0} & =258 \cdot 362 \\
\mathrm{FI} & =99 \cdot 716 \\
\mathrm{R}_{1} / \mathrm{R}_{0} & =1 \cdot 38596
\end{aligned}
$$


Determination of $\delta$.

" $\mathrm{R}_{\mathrm{s}}=679.510$ when barometer $=769 \cdot 20 \mathrm{~mm}$.

" $\mathrm{Pt}_{\mathrm{B}}=\frac{679 \cdot 510-258 \cdot 362}{99 \cdot 716}=422^{\circ} \cdot 35$.

"Now the boiling-point of sulphur at $769 \cdot 20 \mathrm{~mm}$.

$$
\begin{gathered}
\quad=444^{\circ} \cdot 53+0^{\circ} \cdot 082 \times 9 \cdot 20=445^{\circ} \cdot 28 . \\
\therefore 445^{\circ} \cdot 28-422^{\circ} \cdot 35=\delta\left\{(4 \cdot 453)^{2}-4.453\right\},
\end{gathered}
$$

"Final Results :-

$$
\therefore \delta=1 \cdot 491 \text {. }
$$

$$
\begin{aligned}
& \mathrm{R}_{1}=358.078 \\
& \mathrm{R}_{0}=258.362 \\
& \hline \mathrm{FI}=99 \cdot 716
\end{aligned}
$$

$$
\begin{aligned}
\frac{\mathrm{R}_{1}}{\mathrm{R}_{0}} & =1 \cdot 38596 \\
\delta & =1.491 .,
\end{aligned}
$$

\section{Results of Comparisons.}

In order to show in detail the method of comparison, we have selected at random the results of a single comparison of Baudin 6166 with the platinum thermometer (Table XI.).

In Columns II., III., and IV. are shown respectively the coils used, the bridge-wire reading, and temperature of coils, for the measurement of the resistance of the platinum thermometer. The corresponding stem-reading on the mercurial thermometer, taken at the same instant, is shown in column VIII. The temperature of the air near the portion of the stem of the Baudin thermometer projecting from the calorimeter, and of the water in the small water-jacket around the stem, where it emerges from the calorimeter, is shown in columns IX. and $X$.

The resistance of the platinum thermometer is deduced from the observed quantities, shown in columns II., III., and IV., as follows :- To the nominal value of the coils is applied the "coil-correction" to reduce to mean box-units; these are taken from Table I., and are designated "coil cor." in colvmn II. ; a further correction for the temperature of the coils must be applied to reduce to " the mean box-unit of Box No. 7 at $20^{\circ}$ C.."; these corrections are applied in column IV. To the bridge-wire reading is applied the "calibration correction" to reduce the observed reading to mean box-units; to this must be further applied the "zero correction," which takes into account the amount by which the zero of the vernier differs from the zero of the scale when the bridge is balanced with the intervals $\mathrm{C}_{1} \mathrm{C}_{2}$ and $\mathrm{P}_{1} \mathrm{P}_{2}$ short- 
circuited and all plugs replaced with care; these corrections are applied in column III.

By the application of these corrections, taken with proper signs, we get $R$, the resistance of the platinum thermometer, shown in column $\mathrm{V}$.

The platinum temperature, shown in column VI., is deduced from the observed value of $\mathrm{R}$ by substitution in the formula defining platinum temperature, remembering that $\mathrm{R}_{0}=258.471$ and $\mathrm{R}_{1}=358 \cdot 231$ "mean box-units at $20^{\circ} \mathrm{C}$."

From the platinum temperature the corresponding temperature on the air-scale, shown in cclumn VII., is deduced by the formula

$$
t-p t=1 \cdot 491\left\{\left(\frac{t}{100}\right)^{2}-\frac{t}{100}\right\} .
$$

In order to facilitate these reductions, a table was constructed giving the value of $(t-p t)$ for every degree $p t$ on the platinum scale.

Six determinations of the zero of Baudin 6166 gave the following results:-

$$
\begin{aligned}
& \text { min. } \\
& 24 \cdot 159 \\
& 24 \cdot 147 \\
& 24 \cdot 151 \\
& 24 \cdot 148 \\
& 24 \cdot 151 \\
& \text { Mean . . } \frac{24 \cdot 154}{24 \cdot 1.5}
\end{aligned}
$$

Rowland's zero (table xx. p. 116, Proc. Amer. Acad. of Arts and Sciences, xv. 1879) was 20.43.

Temperatures by Baudin 6166 are reduced as follows :-To the mean stem-reading is applied the stem-correction which is divided into two parts, one portion of the stem extending from $28 \mathrm{~mm}$. to $99 \mathrm{~mm}$. being assumed to be at the temperature of the water in the surrounding jacket, the remainder of the stem at the temperature of the surrounding air. This correction is applied in column XI.; from the corrected stem-reading the corresponding temperature on Rowland's air thermometer is obtained from the results of his comparisons of these thermometers with the air thermometer given in his tables XVIII., XIX., and $\mathrm{xx}$. The temperatures thus obtained must be further corrected by the rise of the zero since Rowland's comparisons : this is shown in column XII, which gives the mean temperature on the Rowland air-scale (obtained through 6166), corresponding to the mean temperature on the Callendar-Griffiths air-scale given in column VII. 


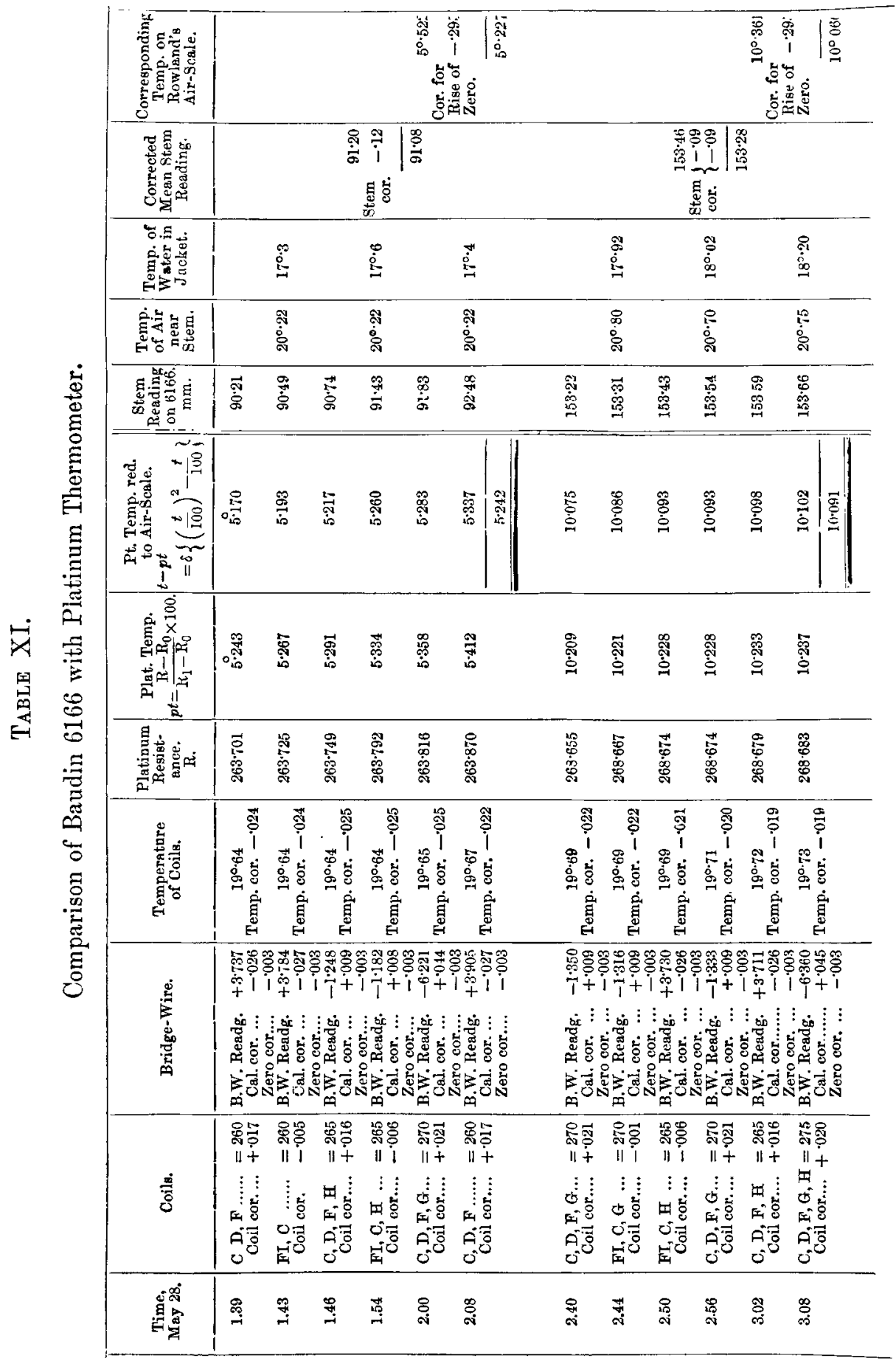




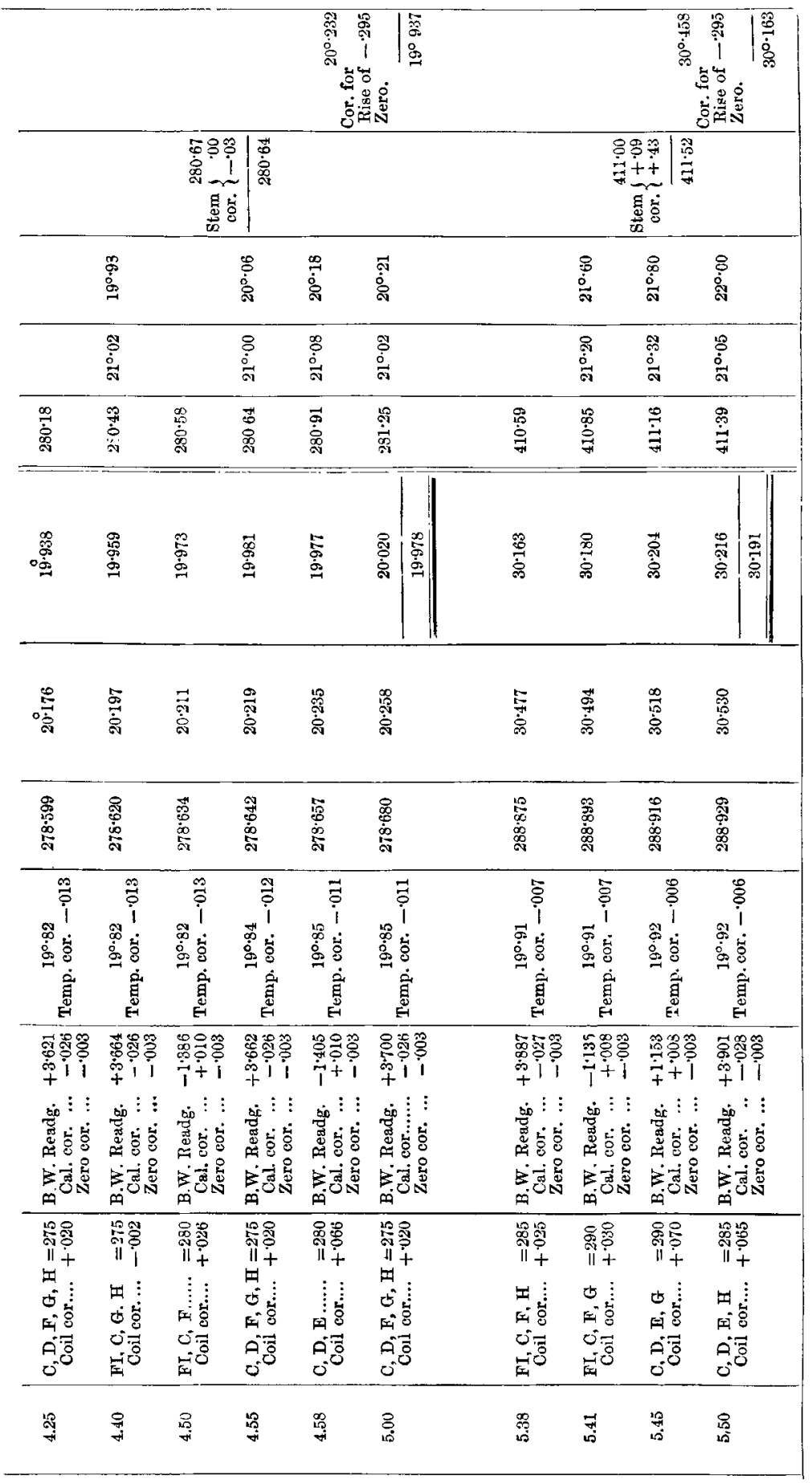




\section{Comparison of Platinum Thermomécer with ToNnelot 11801.}

This comparison was made by Dr. W. S. Day and the authors, in order to bring the results of the different standards of thermometry into comparison, and thus, if possible, to account for the differences in the values of the capacity for heat of water obtained by different observers.

The comparison was carried out in a tank especially designed by Dr. Day for the comparison of mercurial thermometers in a horizontal position. This tank consists of a long rectangular copper box $98 \mathrm{~cm}$. long, $21 \mathrm{~cm}$. wide, and $23 \mathrm{~cm}$. deep, with a movable cover, holding a piece of plate-glass, through which the stem-readings of the thermometers could be observed by means of a micrometer-telescope which slides along parallel ways supported from the cover of the tank. Within this copper tank was another small brass box, $10.5 \mathrm{~cm}$. long, $8 \mathrm{~cm}$. wide, and $5 \mathrm{~cm}$. deep, in which were placed side by side the bulbs of the thermometers to be compared. This box shielded the bulbs from the effects of convection-currents; and in this way the thermometers were kept at a constant temperature for a considerable time, for it required an interval of some minutes for a very appreciable change in the temperature of the large mass of surrounding water to produce a minute change in the temperature of the enclosed water owing to the absence of convection-currents. This brass box was provided with two movable lids on the top and two on the bottom, which could be opened and closed from the outside of the tank. The large tank was provided with three paddle-wheels, operated from the outside, which produced efficient stirring. 'The entire tank was then placed inside a wooden box, the interspace between the walls of the tank and box being loosely filled with cotton-wool. The greater portion of the lid, with the exception of the plate-glass, was covered with a layer of thick felt. The tank and its contents could be raised to any desired temperature by allowing steam to flow through a copper tube coiled along the bottom of the tank.

As the platinum thermometer is peculiarly adapted to show minute changes in temperature, the efficiency of this tank wils exposed to a severe test in these comparisons. It was thus ascertained that if the lids of the inner brass box were opened, the entire contents of the tank thoroughly stirred, and the lids then tightly closed, the temperature would remain constant to within $0^{\circ} .001$ for at least several minntes, for a difference of $20^{\circ}(\%$ between the temperature of the room and the water in the tank. 


\section{Constants of Tonnelot 11801.}

Tonnelot's 11800, 11801, and 11811 were made of French "verre-dur," with transparent stems divided into tenths of a degree, about December 1895 . They were subsequently sent to the Bureau International, where a most exhaustive study of them was made by M. Guillaume, and comparisons made at several different temperatures with their standards. These standards have been compared by M. Chappuis with the standard nitrogen and hydrogen thermometer (Trav. et Mém. du Bur. Int. des Poids et Mesures, tom. vi. 1888), so that the scale of these thermometers can at once be reduced to the nitrogen or hydrogen scale.

We can only briefly outline the methods used at the Bureat International for the standardization of thermometers; for to do full justice to their beautiful and painstaking researches on thermometry would not lie within the limits of the present eommunication.

The thermometers are first roughly examined for uniformity of bore and graduation. If these are not sufficiently accurate, the thermometer is rejected. If these are found satisfactory, a calibration is next made by measuring the lengths of suitable columns of mercury in different portions of the scale. 'This determines the correction that must be applied to certain "principal points" of the scale, to reduce the scale-reading to what the reading would have been if the bore had been perfectly uniform. In these thermometers, whose range includes $0^{\circ}$ and $100^{\circ}$, the corrections are usually so calculated that the calibration corrections for $0^{\circ}$ and $100^{\circ}$ are zero.

The next constants determined are the external and internal pressure-coefficients, usually denoted by $\beta_{e}$ and $\beta_{i}$. The $e x-$ ternal pressure-coefficient is determined by subjecting the thermometer to known varjations in pressure and observing the corresponding change in the stem-reading. The external pressure-coefficient, $\beta_{e}$, is then the change in degrees produced by a change in the external pressure of $1 \mathrm{~mm}$. of mercury. The internal pressure-coefficient, $\beta_{i}$, is deduced from $\beta_{e}$ by adding $0^{\circ} .0000154$, a quantity depending on the difference of compressibility of mercury and "verre-dur."

The fundamental interval, i. e., the number of scale-divisions between $0^{\circ}$ and $100^{\circ}$, is then determined by observing the "fixed points" (in steam and ice) of the thermometer. This gives the value of the degree or the scale-division (if the graduation is arbitrary) on the centigrade scale.

From these known constants the temperature on the centigrade scale of this particular thermometer can be de- 
termined. But a scale of temperature defined in this way would vary with each different specimen of glass used, and would not be exactly the same even for the same kind of glass. The mean scale of a number of French hard-glass thermometers kept at the Bureau International, which have been compared directly with the gas-thermometers $(\mathrm{H}, \mathrm{N}$, and $\mathrm{CO}_{2}$ ), defines temperature on the French hard-glass ("verre-dur") scale. The slight deviations of the hard-glass scale of any other Tonnelot thermometer which is compared with these standards is observed, and these corrections serve to reduce the indications of this thermometer to the mean French hard-glass scale.

\section{Method of Comparison.}

The Tonnelot thermometer was adjusted with its stem in a horizontal position in the comparison-tank, and with its bulb near the centre of the inner brass box. The micrometertelescope was then adjusted by means of a level, so that its axis of collimation was perpendicular to the stem of the thermometer. When these adjustments had been made, no certain difference could be detected between observations made with the divisions in front of the stem and those made with divisions back of the stem. The glass stem of the platinum thermometer passed from the outside through the sides of the wooden box and comparison tank into the brass box, where its coil was almost in contact with the bulb of the mercury thermometer. Before taking an observation the top and bottom of this box were opened, and the entire contents of the tank thoroughly stirred; the lids were then tightly elosed, and a series of observations taken. A single series included a setting on the division below the meniscus, on the meniscus, and on the division above the meniscus, repeated three times, but in inverse order. No certain variation of trmperature was ever detected during the time required to take a series of observations. The box containing the bulbs was then opened, the water again thoroughly stirred, the box closed, and a similar series of observations taken. If the temperature of the water in the tank was below that of the room, after each stirrring there was a slight rise in temperature: if the temperature of the water in the tank was above that of the room, there would be a slight decrease after each stirring: steam was therefore passed through the heating-coil to make sure of a rising meniscus. Usually four such series of observations were taken at each temperature. Immediately after the com- 
Comparisons of Mercury and Platinum Thermometers. 33

parisons at one temperature were completed, the Tonnelot was removed from the tank and its zero quickly determined (in a mixture of pure ice and distilled water) before any recovery of the zero had taken place. In the zero determinations the thermometer was adjusted vertical and the axis of collimation of the micrometer-telescope horizontal. Occasional barometer readings were taken to reduce the indications of the Tonnelot thermometer to standard pressure.

While one observer was taking observations on the Tonnelot thermometer, another observer was taking simultaneous observations of the resistance of the platinum thermometer.

\section{Results of Comparison.}

In order to show in detail the methods used, \&c., we give below the reduction of a single series of observations at one temperature.

Observations:-

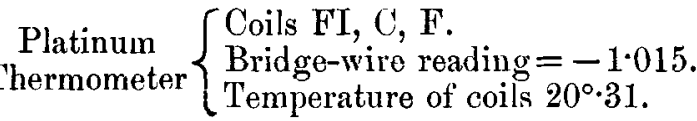

$$
\begin{aligned}
& \text { Micrometer Readings. }
\end{aligned}
$$

\begin{tabular}{|c|c|c|}
\hline \multirow{4}{*}{$\begin{array}{l}\text { Tonnelot } \\
\text { Thermometer } \\
\text { No. } 11801 .\end{array}$} & $\begin{array}{llll}20^{\circ} \cdot 4 & \ldots . . & 15 \cdot 587 \\
\text { Meniscus } & \ldots & 15 \cdot 109 \\
20^{\circ} \cdot 5 & \ldots \ldots & 14 \cdot 995\end{array}$ & $\begin{array}{c}12 \\
15 \cdot 579 \\
15 \cdot 102 \\
14 \cdot 995\end{array}$ \\
\hline & \multicolumn{2}{|c|}{$\begin{array}{l}\text { Barometer (brass scale)... } 762 \\
\text { Temperature } \\
\text { Te............. }\end{array}$} \\
\hline & \multicolumn{2}{|c|}{ Zero determination :- } \\
\hline & $\begin{array}{l}0 . \ldots \ldots \ldots \\
\text { Meniscus ... } 12.42\end{array}$ & \\
\hline
\end{tabular}

Reductions:-

Stem-reading of Tonnelot $11801 \ldots \quad 20.482$

Calibration correction

$$
+0.004
$$

Correction for external pressure due

$$
\left.\begin{array}{l}
\text { to } 57 \mathrm{~mm} \text {. of water }+ \text { excess of } \\
\text { atmospheric pressure. }
\end{array}\right\}-0.001-0.001 \text {. }
$$

Internal pressure correction : ther-

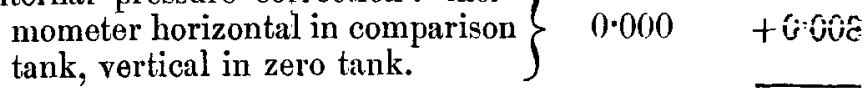

$$
\text { Zero correction ................... }-0.038 \quad \overline{+0.038}
$$

Correction to fundamental interval... $\quad 0 \cdot 000$

Phil. Mag. S. 5. Vol. 48. No. 290. July 1899. 
Temperature on scale of $11801 \ldots \ldots, 20^{\circ} \cdot 447$

Correction $\mathbf{M}$, to reduce to mean
French hard-glass scale.

Temperature on mean hard-glass
scale. $20^{\circ} \cdot 441$

Correction to hydrogen scale........ -0.086

$" \quad$ nitrogen,$\ldots . . . . . \quad-0.076$

Temperature on hydrogen scale $\ldots \quad \overline{20 \cdot 355}$

" "nitrogen,$\quad \ldots \quad 20.365$

Coils FI, C, F ….......... $=280$

Coil corrections (Table I.) ........ + 0.026

Temperature correction ............ + 0.023

Bridge-wire reading ............. -1.015

Calibration correction (Table II.). + 0.007

Zero correction of bridge-wire ... -0.006

$279 \cdot 035$ mean box-units.

$$
\begin{aligned}
\therefore \quad p t & =\frac{279 \cdot 035-258 \cdot 471}{358 \cdot 231-258 \cdot 471} \times 100 \\
& =20^{\circ} \cdot 613 ; \\
\therefore \quad t & =20^{\circ} \cdot 372 \text { (air-scale). }
\end{aligned}
$$

The results of the two independent series of comparisons of the Platinum Thermometer with Tonnelot 11801 are given in the following table (XII.).

\begin{tabular}{|c|c|c|c|c|c|}
\hline $\begin{array}{c}\text { Tonnelot } \\
\text { 11801. } \\
\text { Nitrogen. } \\
\text { Scale. }\end{array}$ & $\begin{array}{c}\text { Pt. Therm. } \\
\text { Air-Scale. }\end{array}$ & $\begin{array}{c}\Delta \\
\text { [Cor. to reduce } \\
\text { Pt.-Air Scale } \\
\text { to Paris } \\
\text { Nitrogen-Scale.] }\end{array}$ & $\begin{array}{c}\text { Tonnelot } \\
11801 . \\
\text { Nitrogen- } \\
\text { Scale. }\end{array}$ & $\begin{array}{l}\text { Pt. Therm. } \\
\text { Air-Scale. }\end{array}$ & $\begin{array}{c}\Delta \\
\text { [Cor. to reduce } \\
\text { Pt.-Air Scale } \\
\text { to Paris } \\
\text { Nitrogen-Scale. }\end{array}$ \\
\hline$\stackrel{\circ}{7 \cdot 804}$ & $7 \cdot 800$ & +004 & $10 \cdot 197$ & $10^{\circ} \cdot 186$ & $+\cdot 011$ \\
\hline $12 \cdot 941$ & $12 \cdot 941$ & $\cdot 000$ & $20 \cdot 519$ & $20 \cdot 523$ & -.004 \\
\hline $18 \cdot 332$ & $18 \cdot 327$ & $+\cdot 005$ & $23 \cdot 400$ & $23 \cdot 391$ & +009 \\
\hline $23 \cdot 106$ & $23 \cdot 114$ & -008 & $25 \cdot 568$ & $25 \cdot 571$ & $-\cdot 003$ \\
\hline $33 \cdot 703$ & $33 \cdot 704$ & $-\cdot 001$ & $30 \cdot 004$ & $30 \cdot 005$ & -.001 \\
\hline 39.999 & $40^{\circ} 001$ & $-\cdot 002$ & $43 \cdot 817$ & $43 \cdot 820$ & -003 \\
\hline
\end{tabular}

\section{TABLE XII.}

Comparison of Platinum Thermometer and Tonnelot 11801.

These results are also plotted in the form of a curve in fig. 5 . 
Comparisons of Mercury and Platinum Thermometers. 35

Fig. 4.

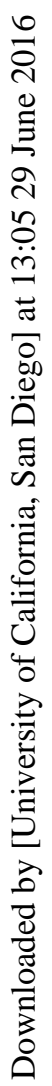

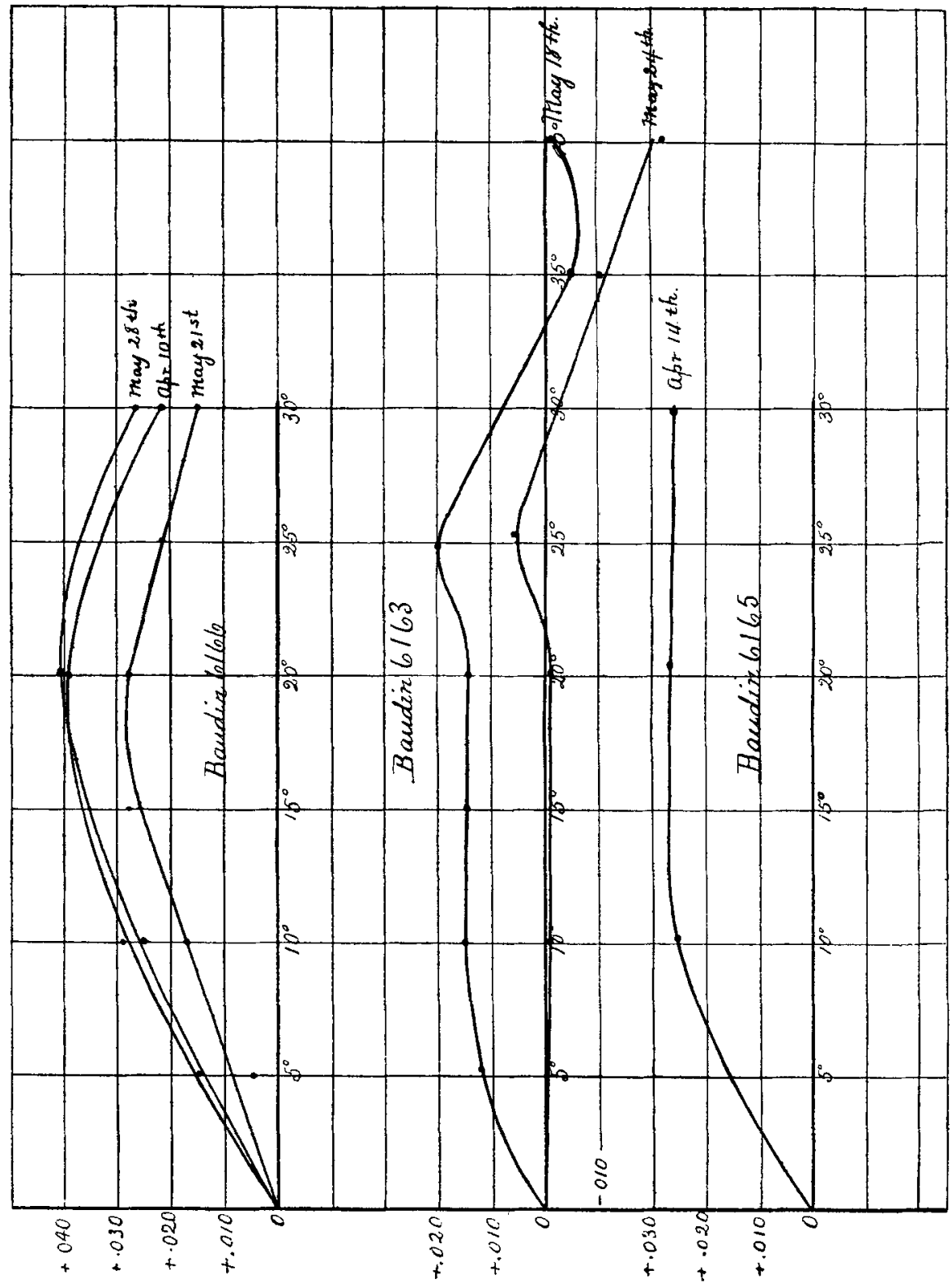

D 2 
The results of these comparisons can best be shown by means of the accompanying curves.

Fig. 4 shows the result of each of the independent comparisons of Professor Rowland's Baudin thermometers with the platinum-resistance thermometer. Abscissæ represent temperature on the centigrade scale, and ordinates the corresponding corrections that must be added to Rowland's air-scale, as determined by the Baudin thermometers, to reduce to the Callendar-Griffiths' air-scale. The almost constant difference between the curves of May 18th and May 24th suggests at once a constant error affecting the entire series of one or the other comparisons. This difference is, however, not of any great importance; for in the determination of the mechanical equivalent we are practically only concerned with temperature ranges over the interval $5^{\circ}$ to $35^{\circ}$, and these are practically identical on either curve. After looking over the results, we bave attributed these differences to a slight error in the value of the temperaturecoefficient of the coils of the box, which, on account of the high temperature of the room, could not be kept at $20^{\circ}$ in the comparisons of May 24th and May 21st. Tbis conclusion is further strengthened by the fact that the comparison of May 28th, when the box was again near $20^{\circ}$, practically coincides with that of April 10th.

A résumé of all the comparisons between the Platinum and Baudin thermometers is also given in the table opposite.

Fig. 5 gives the final correction curves for each of the Baudin thermometers. The ordinates of curves I. (mean of the individual comparisons shown in fig. 4) give the corrections that must be added to Rowland's air-scale, as determined from the Baudin thermometers, to reduce to the Callendar-Griffiths' air-scale. To pass from the air-scale to the absolute scale of temperature use was made of Rowland's table xvir. (p. 114, Proc. Am. Acad. xv. 1879). In this way curves II. were obtained which give the corrections to reduce Rowland's absolute scale to the Callendar-Griffiths' air-scale.

The results of the comparison of the platinum-resistance thermometer with Tonnelot 11801, which had been standardized at the Bureau International, are shown in curve A, in which ordinates represent the corrections that must be added to the Callendar-Griffiths' air-scale to reduce to the Paris nitrogen-scale as given by Tonnelot 11801 . The close agreement of these two scales is a strong confirmation of the accuracy of the platinum-air interpolation formula. Indeed such close agreement must be partly fortuitous, as we have certainly no right to expect so close an agreement, con. sidering the difficulties of gas-thermometry. 
Comparisons of Mercury and Platinum Thermometers. 37 Table XIII.

\begin{tabular}{|c|c|c|c|c|}
\hline Date. & $\begin{array}{c}\text { No. of } \\
\text { Observations. }\end{array}$ & $\begin{array}{c}\text { Temp. on } \\
\text { Callendar- } \\
\text { Griffiths } \\
\text { Air-Scale. }\end{array}$ & $\begin{array}{c}\text { Temp. on } \\
\text { Rowland's } \\
\text { Air-Scale. }\end{array}$ & $\begin{array}{c}\text { Difference } \\
\Delta .\end{array}$ \\
\hline \multicolumn{5}{|c|}{ Comparison of Platinum Thermometer with Baudin 6163.} \\
\hline May 18th. & $\begin{array}{l}5 \\
6 \\
6 \\
6 \\
4 \\
5 \\
4\end{array}$ & $\begin{array}{r}0 \\
5 \cdot 261 \\
9 \cdot 937 \\
15 \cdot 340 \\
20 \cdot 066 \\
24 \cdot 881 \\
34 \cdot 916 \\
40 \cdot 051\end{array}$ & $\begin{array}{r}9 \\
5 \cdot 249 \\
9 \cdot 922 \\
15 \cdot 325 \\
20 \cdot 052 \\
24 \cdot 861 \\
34 \cdot 921 \\
40 \cdot 052\end{array}$ & $\begin{array}{l}+0.012 \\
+0.015 \\
+0.015 \\
+0.014 \\
+0.020 \\
-0.005 \\
-0.001\end{array}$ \\
\hline \multicolumn{5}{|c|}{ Comparison of Platinum Thermometer with Baudin 6163.} \\
\hline May 24th. & $\begin{array}{l}6 \\
6 \\
6 \\
6 \\
6 \\
6\end{array}$ & $\begin{array}{r}8 \cdot 997 \\
20 \cdot 055 \\
25 \cdot 228 \\
34 \cdot 899 \\
40 \cdot 283\end{array}$ & $\begin{array}{r}\stackrel{8}{9} \cdot 998 \\
20 \cdot 056 \\
25 \cdot 222 \\
34 \cdot 909 \\
40 \cdot 305\end{array}$ & $\begin{array}{l}-0.001 \\
-0.001 \\
+0.006 \\
-0.010 \\
-0.022\end{array}$ \\
\hline \multicolumn{5}{|c|}{ Comparison of Platinum Thermometer with Baudin 6166.} \\
\hline Apr. 10th. & $\begin{array}{l}5 \\
5 \\
5\end{array}$ & $\begin{array}{l}10.873 \\
19 \cdot 650 \\
30 \cdot 136\end{array}$ & $\begin{array}{l}10 \cdot 844 \\
19 \cdot 611 \\
30 \cdot 114\end{array}$ & $\begin{array}{l}+0029 \\
+0.039 \\
+0.022\end{array}$ \\
\hline \multicolumn{5}{|c|}{ Comparison of Platinum Thermometer with Baudin 6166.} \\
\hline May 21st. & $\begin{array}{l}5 \\
6 \\
6 \\
7 \\
6 \\
6\end{array}$ & $\begin{array}{r}0 \\
5 \cdot 131 \\
9 \cdot 869 \\
14 \cdot 899 \\
19 \cdot 951 \\
24 \cdot 987 \\
30 \cdot 226\end{array}$ & $\begin{array}{r}\circ \cdot 127 \\
5 \cdot 127 \\
9 \cdot 852 \\
14 \cdot 871 \\
19 \cdot 923 \\
24 \cdot 965 \\
30 \cdot 212\end{array}$ & $\begin{array}{l}+0.004 \\
+0.017 \\
+0.028 \\
+0.028 \\
+0.022 \\
+0.015\end{array}$ \\
\hline \multicolumn{5}{|c|}{ Comparison of Platinum Thermometer with Baudin 6166.} \\
\hline May 28th. & $\begin{array}{l}6 \\
6 \\
6 \\
4\end{array}$ & $\begin{array}{r}5 \cdot 242 \\
50 \cdot 091 \\
19 \cdot 978 \\
30 \cdot 191\end{array}$ & $\begin{array}{r}5 \cdot 227 \\
10 \cdot 066 \\
19 \cdot 937 \\
30 \cdot 163\end{array}$ & $\begin{array}{l}+0.015 \\
+0.025 \\
+0.041 \\
+0.028\end{array}$ \\
\hline \multicolumn{5}{|c|}{ Comparison of Platinum Thermometer with Baudin 6165.} \\
\hline Apr. 14th. & $\begin{array}{l}5 \\
5 \\
5\end{array}$ & $\begin{array}{l}10 \cdot 129 \\
20 \cdot 274 \\
29 \cdot 735\end{array}$ & $\begin{array}{l}10 \cdot 104 \\
20 \cdot 247 \\
29 \cdot 709\end{array}$ & $\begin{array}{l}+0.025 \\
+0.027 \\
+0.026\end{array}$ \\
\hline
\end{tabular}


Fig. 5.

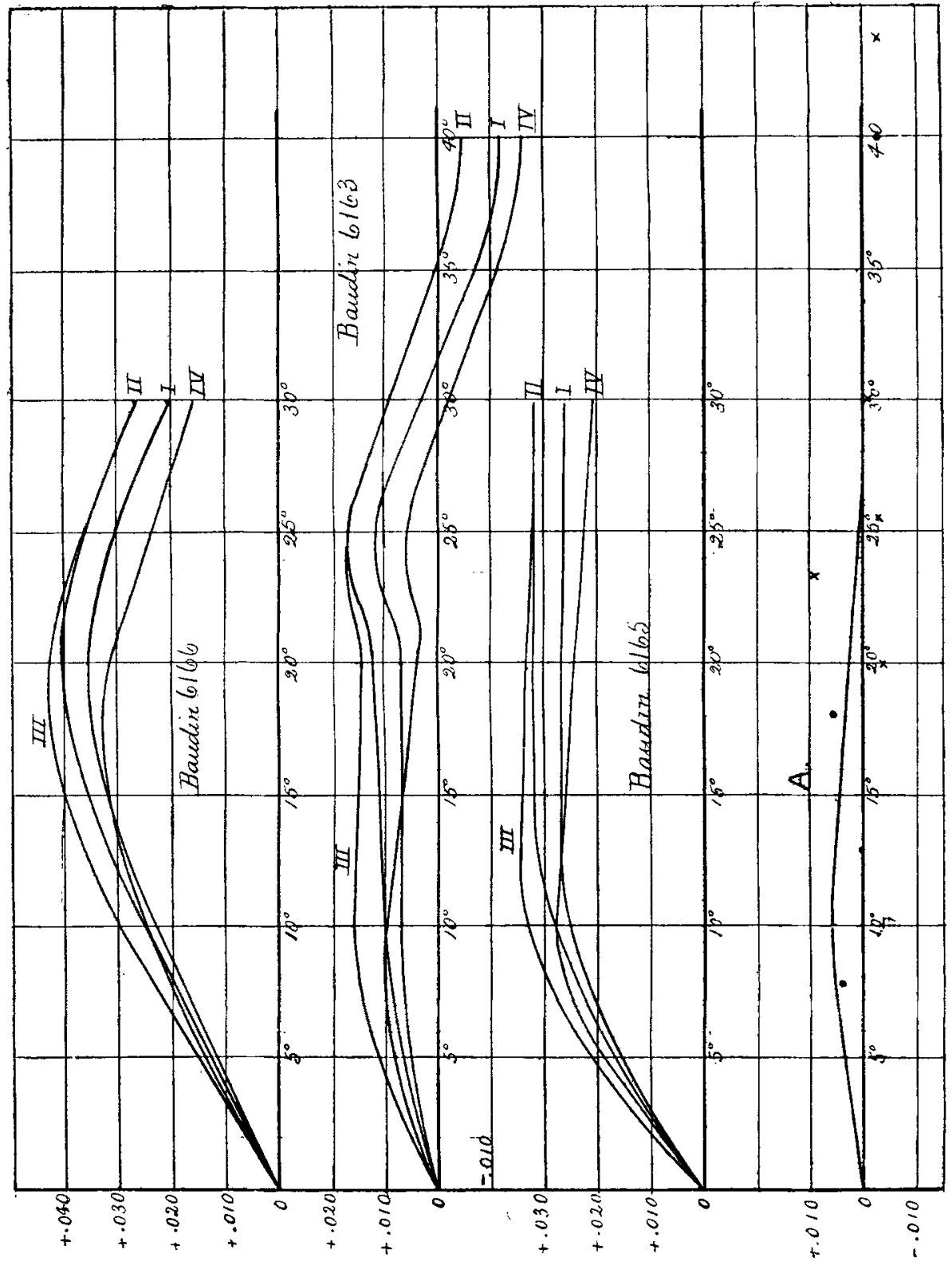


Comparisons of Mercury and Platinum Thermometers. 39

Curves III., whose ordinates must be added to Rowland's absolute scale to reduce this to the Paris nitrogen-scale, were then obtained by combining curves II. and eurve A.

\section{TABLE XIV.}

Corrections to Rowland's Baudin Thermometers.

\begin{tabular}{|c|c|c|c|c|c|c|}
\hline \multirow[b]{2}{*}{$\begin{array}{c}\text { 'I'emp. } \\
\circ \text { o. }\end{array}$} & \multicolumn{2}{|c|}{ Baudin 6163.} & \multicolumn{2}{|c|}{ Baudin 6165.} & \multicolumn{2}{|c|}{ Baudin 6166.} \\
\hline & $\begin{array}{l}\text { Col. to } \\
\text { Paris } \\
\text { Nitrogen- } \\
\text { Scale. }\end{array}$ & $\begin{array}{c}\text { Cor. to } \\
\text { Paris } \\
\text { Hydrogen- } \\
\text { Scale. }\end{array}$ & $\begin{array}{l}\text { Cor. to } \\
\text { Paris } \\
\text { Nitrogen- } \\
\text { Scale. }\end{array}$ & $\begin{array}{c}\text { Cor. to } \\
\text { Paris } \\
\text { Hydrogen- } \\
\text { Scale. }\end{array}$ & $\begin{array}{l}\text { Cor. to } \\
\text { Paris } \\
\text { Nitrogen- } \\
\text { Scale. }\end{array}$ & $\begin{array}{c}\text { Cor. to } \\
\text { Paris } \\
\text { Hydrogen- } \\
\text { Scale. }\end{array}$ \\
\hline $1^{\circ}$ & $+000^{\circ}$ & $+\cdot(102$ & +006 & +.005 & +0104 & .003 \\
\hline 2 & .004 & .003 & .010 & '009 & .007 & .005 \\
\hline 3 & $\cdot 006$ & .005 & 015 & .013 & .010 & -008 \\
\hline 4 & .009 & .007 & .019 & 016 & .013 & 010 \\
\hline 5 & 011 & 008 & 022 & .019 & .016 & $01: 3$ \\
\hline 6 & .013 & .009 & .025 & $\cdot(1) 22$ & 019 & .015 \\
\hline 7 & .014 & .010 & .027 & .024 & .022 & $\cdot 017$ \\
\hline 8 & .015 & .011 & .030 & $\cdot 0 \cdot 26$ & -0.25 & .019 \\
\hline 9 & .015 & .011 & .032 & -028 & $\cdot 027$ & $\cdot 021$ \\
\hline 10 & .016 & .010 & .034 & .028 & .030 & .024 \\
\hline 11 & .015 & .009 & .035 & $\cdot 028$ & $\cdot 032$ & $\cdot 025$ \\
\hline 12 & .015 & .009 & $\cdot 036$ & .028 & 034 & 0.27 \\
\hline 13 & .015 & .007 & .036 & .028 & .037 & $\cdot 029$ \\
\hline 14 & .015 & .007 & .036 & .027 & 038 & .031 \\
\hline 15 & .015 & .007 & .036 & $\cdot 027$ & $\cdot 040$ & .032 \\
\hline 16 & .015 & .006 & -035 & 026 & $\cdot 041$ & -033 \\
\hline 17 & .015 & $\cdot 006$ & -035 & $\cdot 096$ & .042 & 034 \\
\hline 18 & 014 & .005 & .035 & 4025 & 043 & .034 \\
\hline 19 & .014 & $\cdot 005$ & .035 & .025 & .043 & .034 \\
\hline 20 & .014 & $00 t$ & .034 & .024 & .043 & .033 \\
\hline 21 & -015 & .004 & .033 & .023 & .042 & .031 \\
\hline 22 & .016 & .004 & .033 & .023 & .041 & .029 \\
\hline 23 & .017 & .005 & .033 & .022 & $\cdot 039$ & .028 \\
\hline 24 & 017 & .006 & -033 & .021 & .037 & $\cdot 026$ \\
\hline 25 & .017 & .006 & $\cdot 032$ & 021 & .035 & .024 \\
\hline 26 & .016 & .005 & .032 & .021 & .034 & $02 *$ \\
\hline 27 & .015 & .003 & .032 & 021 & .032 & 021 \\
\hline 28 & .013 & .002 & .032 & .021 & .030 & $\cdot 019$ \\
\hline 29 & .011 & .000 & 032 & .021 & .028 & .017 \\
\hline 30 & .009 & -.002 & .032 & .021 & $.02 \pi$ & .016 \\
\hline 31 & .007 & $-.00 t$ & & & & \\
\hline 32 & .005 & -.005 & & & & \\
\hline 33 & .003 & -007 & & & & \\
\hline 34 & .002 & -.009 & & & & \\
\hline 35 & $\cdot 000$ & -.011 & & & & \\
\hline 36 & -.002 & -.013 & & & & \\
\hline 37 & -003 & -015 & & & & \\
\hline 38 & -.004 & -016 & & & & \\
\hline 39 & -.005 & -016 & & & & \\
\hline 40 & -005 & -.016 & & & & \\
\hline 41 & -006 & -017 & & & & \\
\hline
\end{tabular}


Curves IV. give the corrections that must be added to Rowland's absolute scale to reduce this to the Paris hydrogenscale; these curves are obtained from curves III. by making use of the relation of the hydrogen and nitrogen scales of temperature as determined by the experiments of $M$. Chappuis (Guillaume, 'Thermomètrie de Précision,' p. 258).

The corrections to reduce the readings of the Baudin thermometers (when referred to Rowland's absolute scale) to the Paris nitrogen and hydrogen scales of temperature, as obtained from curves III. and IV. fig. 5, are given in Table XIV.

Recaluulation of Mechanical Equivalent.

Reduction to the Paris Nitrogen-Scale.-Rowland's values of the mechanical equivalent, as expressed in terms of the rise of temperature of water, are deduced from an equation of the following form :-

$$
J_{\mathrm{T}^{\circ}}=\frac{\mathrm{W}}{\left(\mathrm{T}+5^{\circ}\right)-\left(\mathrm{T}^{\circ}-5^{\circ}\right)},
$$

where $\mathrm{W}$ is equal to the energy in ergs required to raise the temperature of the water from $\mathrm{T}^{\circ}-5^{\circ}$ to $\mathrm{T}^{\circ}+5^{\circ}$.

Hence, if $\mathrm{C}_{20}$ and $\mathrm{C}_{10}$ are the corrections that have to be applied to the temperature indicated by the Baudin thermometers to reduce these to the Paris nitrogen-scale, we shall have for the value of $J_{10^{\circ}}$ reduced to the nitrogen-scale :-

$$
\begin{aligned}
\mathrm{J}_{15^{\circ}}^{\mathrm{N}} & =\frac{\mathrm{W}}{\left(20^{\circ}+\mathrm{C}_{20}\right)-\left(10^{\circ}+\mathrm{C}_{10}\right)}=\frac{\mathrm{W}}{10} \frac{1}{1+\frac{\mathrm{C}_{20}-\mathrm{C}_{10}^{\circ}}{10}} \\
& =\mathrm{J}_{15^{\circ}} \frac{1}{1+\frac{\mathrm{C}_{20}-\mathrm{C}_{10}}{10}}=\mathrm{J}_{15}\left(1+\frac{\mathrm{C}_{10}-\mathrm{C}_{20}}{10}\right) \text { approximately } \\
& =\mathrm{J}_{15^{\circ}} \mathrm{K}_{15^{\circ}}, \text { where } \mathrm{K}_{15^{\circ}}=\left(1+\frac{\mathrm{C}_{10}-\mathrm{C}_{20}}{10}\right) .
\end{aligned}
$$

The values of $\mathrm{K}$ (the factor to reduce Rowland's values of the equivalent to the Paris nitrogen-scale) were computed, from the corrections found by the preceding comparisons, for each degree centigrade for each of the Baudin thermometers.

The resuits of Rowland's experiments on the mechanical equivalent of heat are summarized on pp. 192-196, Proc. Am. Acad. xv. 1879.

The values of $J$ at any one temperature were averaged for 
Comparisons of Mercury and Platinum Thermomelers. 41

each thermometer separately, and each mean was then reduced to the nitrogen-scale by the proper correction factor $\mathrm{K}$. The general mean value of $\boldsymbol{J}$ at that temperature was then obtained by taking the mean of the values given by each thermometer, giving to each thermometer a weight equal to the number of experiments performed with that thermometer at the given temperature. These values of $J$, corrected as indicated above, were then plotted, and the values obtained from the resulting smooth curve were taken as the final value of $J$ on the nitrogen-scale. For the sake of comparison, the original as well as the corrected values of $J$ are given in the following table.

TABLE XV.

\begin{tabular}{|c|c|c|c|c|c|}
\hline Temp. & $\begin{array}{c}\text { Rowland } \\
\text { values of J } \\
\text { (absolute seale) } \\
\text { on the C.G.S. } \\
\text { System. }\end{array}$ & \begin{tabular}{|c|} 
Rowland's \\
values of J \\
reduced to Paris \\
Nitrogen-Scale \\
on the C.G.S. \\
System.
\end{tabular} & Temp. & $\begin{array}{l}\text { Rowland's } \\
\text { values of J } \\
\text { (absolute scale) } \\
\text { on the C.G.S. } \\
\text { System. }\end{array}$ & $\begin{array}{c}\text { Rowland's } \\
\text { values of J } \\
\text { reduced to Paris } \\
\text { Nitrogen-Scale } \\
\text { on the C.G.S. } \\
\text { System. }\end{array}$ \\
\hline \begin{tabular}{r|}
$7^{\circ}$ \\
$8^{\circ}$ \\
$9^{\circ}$ \\
$10^{\circ}$ \\
$11^{\circ}$ \\
$12^{\circ}$ \\
$13^{\circ}$ \\
$14^{\circ}$ \\
$15^{\circ}$ \\
$16^{\circ}$ \\
$17^{\circ}$ \\
$18^{\circ}$ \\
$19^{\circ}$ \\
$20^{\circ}$ \\
$21^{\circ}$
\end{tabular} & $\begin{array}{l}4 \cdot 207 \times 10^{7} \\
4 \cdot 204 \\
4 \cdot 202 \\
4 \cdot 200 \\
4 \cdot 198 \\
4 \cdot 196 \\
4 \cdot 194 \\
4 \cdot 19 \cdot \\
4 \cdot 189 \\
4 \cdot 187 \\
4 \cdot 185 \\
4 \cdot 183 \\
4 \cdot 181 \\
4 \cdot 179 \\
4 \cdot 177\end{array}$ & $\begin{array}{l}4200 \times 10^{7} \\
4 \cdot 198 \\
4 \cdot 196 \\
4 \cdot 195 \\
4 \cdot 193 \\
4 \cdot 192 \\
4 \cdot 190 \\
4 \cdot 189 \\
4 \cdot 187 \\
4 \cdot 186 \\
4 \cdot 184 \\
4 \cdot 183 \\
4 \cdot 182 \\
4 \cdot 181 \\
4 \cdot 179\end{array}$ & $\begin{array}{l}22^{\circ} \\
23^{\circ} \\
24^{\circ} \\
25^{\circ} \\
26^{\circ} \\
27^{\circ} \\
28^{\circ} \\
24^{\circ} \\
30^{\circ} \\
31^{\circ} \\
32^{\circ} \\
33^{\circ} \\
34^{\circ} \\
35^{\circ} \\
36^{\circ}\end{array}$ & $\begin{array}{l}4 \cdot 176 \times 10^{7} \\
4 \cdot 175 \\
4 \cdot 174 \\
4 \cdot 173 \\
4 \cdot 172 \\
4 \cdot 171 \\
4 \cdot 171 \\
4 \cdot 170 \\
4 \cdot 171 \\
4 \cdot 171 \\
4 \cdot 171 \\
4 \cdot 172 \\
4 \cdot 172 \\
4 \cdot 173 \\
4: 173\end{array}$ & $\begin{array}{l}4 \cdot 178 \times 10^{7} \\
4 \cdot 177 \\
4 \cdot 177 \\
4 \cdot 176 \\
4 \cdot 175 \\
4 \cdot 175 \\
4 \cdot 174 \\
4 \cdot 174 \\
4 \cdot 175 \\
4 \cdot 175 \\
4 \cdot 175 \\
4 \cdot 175 \\
4 \cdot 176 \\
4 \cdot 177 \\
4 \cdot 178\end{array}$ \\
\hline
\end{tabular}

These results are also plotted in fig. 6 (p. 42). For the sake of comparison the electrical determinations of the mechanical equivalent by Griffiths and by Schuster and Gannon are also shown on the same figure.

\section{Conclusions.}

These comparisons would seem to show that Baudin 6103 , when its indications are reduced to the absolute scale by means of Rowland's tables, reads lower than the Paris nitrogen-scale over the range $0^{\circ}$ to $35^{\circ}$, these differences amounting to $0^{\circ} \cdot 016$ at $10^{\circ}, 0^{\circ} .014$ at $20^{\circ}$, and $0^{\circ} .009$ at $30^{\circ}$. 
Fig. 6.

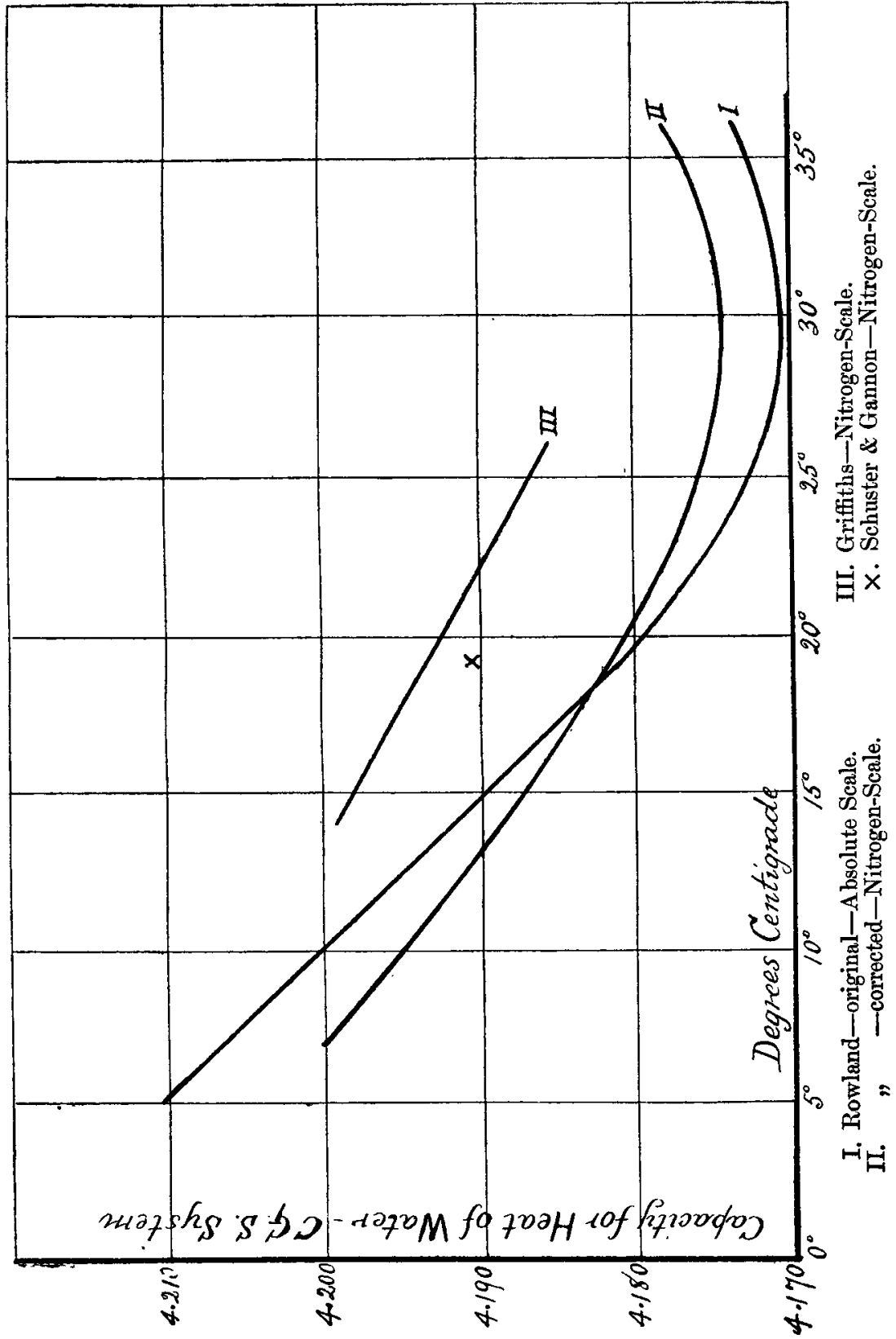


The corrections to reduce to the Paris hydrogen-scale and the Callendar-Griffiths' air-scale are respectively $0^{\circ} .010$ and $0^{\circ} .010$ at $10^{\circ}, 0^{\circ} .004$ and $0^{\circ} .012$ at $20^{\circ}$, and $-0^{\circ} .002$ and $0^{\circ} .009$ at $30^{\circ}$. Baudin 6166 , when its indications are reduced to the absolute scale, reads lower than the Paris nitrogenscale throughout the range $0^{\circ}$ to $31^{\circ}$; the corrections are $0^{\circ} .030$ at $10^{\circ}, 0^{\circ} .043$ at $20^{\circ}$, and $0^{\circ} .027$ at $30^{\circ}$. The corrections to reduce to the Paris hydrogen-scale and the Callendar-Griffiths air-scale are respectively $0^{\circ} .024$ and $0^{\circ} .025$ at $10^{\circ}, 0^{\circ} .033$ and $0^{\circ} .041$ at $20^{\circ}$, and $0^{\circ} .016$ and $0^{\circ} .027$ at $30^{\circ}$. The indications of Baudin 6165 , when reduced to the absolute scale, are about $0^{\circ} 035$ too low throughout the range $10^{\circ}$ to $30^{\circ}$.

As will be seen from the curves for the "capacity for heat of water" shown in fig. 6 , the changes in Rowland's values are small, amounting to a decrease of about 1 part in 850 at $10^{\circ} \mathrm{C}$, , the value at about $18^{\circ}$ remaining unchanged, while those at $20^{\circ}$ and $25^{\circ}$ are respectively increased by about 1 in 2100 and 1 in 1400. The variation of the specific heat of water with temperature between $15^{\circ}$ and $25^{\circ}$, when Rowland's values are referred to the Paris nitrogen-scale, is practically identical with that given by Griffiths' curve. This suggests at once that an explanation of the differences between the mechanical and electrical determinations of the mechanical equivalent must be sought in the energy-measurements.

In Rowland's experiments an error in the energy-measurements may be due either to an error in the diameter of the torsion-wheel of his calorimeter or to the system of weights employed. Inasmuch as the diameter of the torsion-wheel was measured many times by comparison with two standard metre-bars, each of which had been compared with the Coast Survey and other standards, the possibility of an error sufficient to account for the observed differences between the mechanical and electrical determinations must be sought elsewhere. Turning to the question of the weights used in these experiments, we see that it is not necessary that they be correct absolutely with the standards, if they are only relatively correct, as the formula for the mechanical equivalent contains a weight in both numerator and denominator. On the other hand, if they were not correct relatively, we should hardly expect to find the almost constant difference between the determinations of Griffiths and those of Rowland (reduced to nitrogen-scale) throughout the range $15^{\circ}$ to $25^{\circ}$. The evidence accumulated thus far would, we believe, suggest, as a possible explanation of these differences, a still undiscovered 
error in the system of electric units employed. This, indeed, in the light of the enormous and painstaking work which serves as the basis of these units, is not probable, but, considering the difficulties encountered in the standards of electromotive force and current, it is not altogether impossible. The enormous experimental eridence which served as the basis of the international ohm, together with the recent confirmation of the accuracy of this unit, renders it almost certain that the difference need not be looked for in this direction.

At the Toronto meeting of the British Association, before which in abstract of this paper was read, the Committee on Electric Standards received an appropriation for the redetermination of the electrochemical equivalent of silver and the absolute electromotive force of the Clark cell, and their results are awaited with much interest. In the meanlwhile the results of a determination of these quantities, made by Dr. Kahle at the Reichsanstalt, have been published ("Keitschr.f. Instk. xriii. pp. 229, 267, 1898; Wied. Amn. lix. j. 532, 1896; Wied. Ann. lxvii. p. 1, 1899). His final value of the E.M.F. of the German H standard form of Clark cell was

$$
\mathrm{E}_{15^{\circ}}=1 \cdot 432.5 \text { volts. }
$$

By making use of a previous comparison between the Cambridge standiard and the German $\mathrm{H}$ standard (B. A. Report, 1892), the Cambridge standard, when reduced in accordance with Kahle's value, becomes

$$
\text { Cambridge }_{15^{\circ}}=1 \cdot 1329 \text { volts. }
$$

The value of the Cambridge standard (upon which is based Griffiths' values of the capacity for heat of water) as determined by Glazebrook and Skinner (Phil. Trans. A, 1892) was

$$
\text { Cambridge }{ }_{15^{\circ}}=1 \cdot 4342 \text { volts. }
$$

As has already been shown by Dr. F. A. Wolff (Johns Hopkins Univ. Circular, June 1898), when the values of the E.M.F. of the Clark cell, as found by Kahle, are applied to Griffiths' values of the capacity for heat of water, as well as those of Schuster and Gannon, they are brought into very fair agreement with those of Rowland as corrected by the results of our comparisons (differing by about 1 part in 1400). This is shown by the following table:- 
Comparisons of Mercury and Platinum Thermometers. 45

Old.

Corrected.

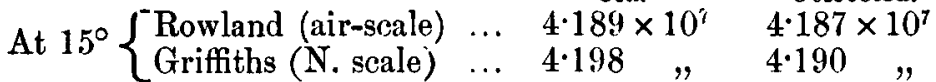

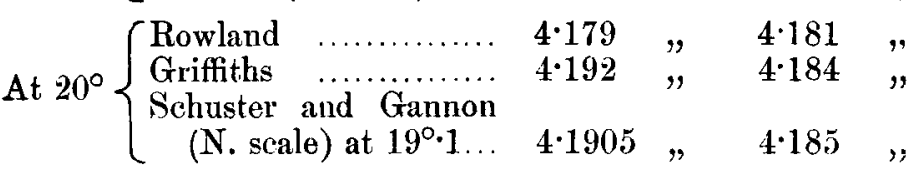

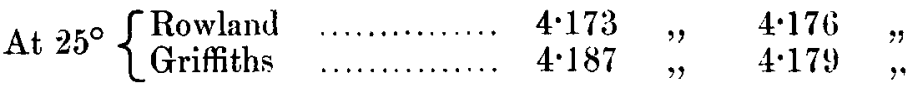

Dr. Guthe has kindly informed me of the result of a redetermination of the electrochemical equivalent of silver, which was carried out during the past year by Professor Patterson ${ }^{*}$ and himself at the University of Michigan. Their final value of the electrochemical equivalent of silver is 0.0011193 gramme per ampere per second for a "used" solution. This is very near the value found by Kahle for a used solution. For a "fresh" solution Kahle found 0.0011182 .

A recalculation of the E.M.F. of the Cambridge standard Clark cell as determined by Glazebrook and Skinner, if we use the value of the equivalent found by Gathe and Patterson, is

$$
\text { Cambridge }_{15^{\circ}}=1.4327 \text { volts, }
$$

which is in very close agreement with the value as given by Kahle. If Griffiths' values are corrected in accordance with this determination, the agreement with Rowland's corrected values is very close, they being greater by about 1 part in 2300 throughout the range $15^{\circ}$ to $25^{\circ}$.

In conclusion the anthors wish to express their sincere appreciation of Professor Rowland's kindness in allowing the use of his thermometers for these comparisons, and their many obligations to Professor Rowland and Professor Ames for their frequent advice and assistance throughout the course of this work; and also to Dr. W. S. Day for so freely placing his apparatus at our disposal, and his many acts of kindness.

Johns Hopkins University, Baltimore.

* The results of this investigation have since been published in the Phys. Rev., Dec. 1898, p. 257. 